\title{
The Impact of Sea Ice Concentration Accuracies on Climate Model Simulations with the GISS GCM
}

\author{
Claire L. PARkinson \\ Oceans and Ice Branch, NASA Goddard Space Flight Center, Greenbelt, Maryland \\ DAVID RIND \\ NASA Goddard Institute for Space Studies, New York, New York, and \\ NASA Goddard Space Flight Center, Greenbelt, Maryland \\ RICHARD J. HEALY \\ Woods Hole Oceanographic Institution, Woods Hole, Massachusetts \\ DOUGLAS G. MARTINSON \\ Lamont-Doherty Earth Observatory, Columbia University, Palisades, New York
}

(Manuscript received 18 October 1999, in final form 19 September 2000)

\begin{abstract}
The Goddard Institute for Space Studies global climate model (GISS GCM) is used to examine the sensitivity of the simulated climate to sea ice concentration specifications in the type of simulation done in the Atmospheric Model Intercomparison Project (AMIP), with specified oceanic boundary conditions. Results show that sea ice concentration uncertainties of $\pm 7 \%$ can affect simulated regional temperatures by more than $6^{\circ} \mathrm{C}$, and biases in sea ice concentrations of $+7 \%$ and $-7 \%$ alter simulated annually averaged global surface air temperatures by $-0.10^{\circ}$ and $+0.17^{\circ} \mathrm{C}$, respectively, over those in the control simulation. The resulting $0.27^{\circ} \mathrm{C}$ difference in simulated annual global surface air temperatures is reduced by a third, to $0.18^{\circ} \mathrm{C}$, when considering instead biases of $+4 \%$ and $-4 \%$. More broadly, least squares fits through the temperature results of 17 simulations with ice concentration input changes ranging from increases of $50 \%$ versus the control simulation to decreases of $50 \%$ yield a yearly average global impact of $0.0107^{\circ} \mathrm{C}$ warming for every $1 \%$ ice concentration decrease, that is, $1.07^{\circ} \mathrm{C}$ warming for the full $+50 \%$ to $-50 \%$ range. Regionally and on a monthly average basis, the differences can be far greater, especially in the polar regions, where wintertime contrasts between the $+50 \%$ and $-50 \%$ cases can exceed $30^{\circ} \mathrm{C}$. However, few statistically significant effects are found outside the polar latitudes, and temperature effects over the nonpolar oceans tend to be under $1^{\circ} \mathrm{C}$, due in part to the specification of an unvarying annual cycle of sea surface temperatures. The $\pm 7 \%$ and $\pm 4 \%$ results provide bounds on the impact (on GISS GCM simulations making use of satellite data) of satellite-derived ice concentration inaccuracies, $\pm 7 \%$ being the current estimated average accuracy of satellite retrievals and $\pm 4 \%$ being the anticipated improved average accuracy for upcoming satellite instruments. Results show that the impact on simulated temperatures of imposed ice concentration changes is least in summer, encouragingly the same season in which the satellite accuracies are thought to be worst. Hence, the impact of satellite inaccuracies is probably less than the use of an annually averaged satellite inaccuracy would suggest.
\end{abstract}

\section{Introduction}

The specification of sea ice variations over time has become a topic of considerable importance both for evaluation of global climate model (GCM) simulations and for assessment of recent climate changes. Model comparison efforts being carried out by the Atmospheric

Corresponding author address: Dr. Claire L. Parkinson, Oceans and Ice Branch, Code 971, NASA Goddard Space Flight Center, Greenbelt, MD 20771.

E-mail: clairep@neptune.gsfc.nasa.gov
Model Intercomparison Project (AMIP) (Gates 1992) provide surface boundary conditions, such as sea surface temperatures and sea ice distributions, for use by different modeling groups and then compare the resulting model simulations and the observed climate variations, for example, over the past two decades. Similarly, researchers such as Hansen et al. (1997) and Folland et al. (1998) use the input datasets along with climate forcings (trace gas and aerosol variations in particular) to compare modeling results with observed distributions and profiles of climate change. In all these 
cases, the ability of the models to produce realistic pressure and temperature changes and the model-derived assessment of the contributions of different forcings to the observed changes are constrained by what the input datasets allow. In particular, Hansen et al. (1997) find that the specified sea ice and sea surface temperature (SST) boundary conditions from AMIP produced a global surface atmospheric warming in the Goddard Institute for Space Studies (GISS) GCM of $0.24^{\circ} \mathrm{C}$ decade $^{-1}$ from 1979 to 1993 , much greater than the observed warming of $0.1^{\circ} \mathrm{C}$ decade $^{-1}$ (Hansen et al. 1997). The excess warming was traced to discontinuities in the AMIP sea ice boundary conditions, leading the researchers to adjust the input data to eliminate the sea ice trend. Among the issues raised by these studies are how well the sea ice trends should be known for effective usage and the magnitude of error introduced by specific percentage inaccuracies in the specified sea ice cover.

The importance of sea ice to model simulations is further highlighted by the finding of Rind et al. (1995) that artificially preventing sea ice changes in the GISS simulations reduced the model's global temperature sensitivity to doubled atmospheric $\mathrm{CO}_{2}$ by $37 \%$ from a $4.17^{\circ}$ warming to a $2.61^{\circ} \mathrm{C}$ warming. This reduced sensitivity resulted both from the elimination of the sea ice albedo feedback (about 1/3 of the effect) and, more importantly, from the mitigation of the water vapor and cloud cover feedbacks brought on by the absence of sea ice albedo changes. Such studies suggest that the Arctic sea ice extent decreases over the last two decades (e.g., Bjørgo et al. 1997; Parkinson et al. 1999) might be a harbinger of future increased climate change, although the effect of sea ice changes on climate sensitivity might be overestimated, for example, if the modeled water vapor feedbacks (questioned by Lindzen 1990) are excessive. Uncertainties arise also from several recent evaluations of GCM simulations, which have specifically highlighted difficulties in the simulation of polar climates (e.g., Walsh and Crane 1992; Bromwich et al. 1994; McGinnis and Crane 1994; Cattle and Crossley 1995; Battisti et al. 1997).

The model results and the uncertainties in them both contribute to the recognition of a need to monitor sea ice changes closely and to evaluate these changes in the context of numerical simulations. Although detailed global sea ice datasets were not feasible prior to the satellite era, for the past two decades sea ice concentrations (percent areal coverages of sea ice) have been routinely obtainable from satellite data to an estimated accuracy of about $\pm 7 \%$ (Gloersen et al. 1992) using the multichannel passive-microwave data of the Nimbus-7 Scanning Multichannel Microwave Radiometer (SMMR) and the Defense Meteorological Satellite Program (DMSP) Special Sensor Microwave/Imagers (SSM/Is). The lack of ground truth makes the accuracy estimates difficult to verify, but partial verifications have come from comparisons with other satellite datasets (e.g., Steffen and Schweiger 1991). Because snowmelt, ice melt, and meltponding complicate the microwave signal received by the satellite (e.g., Gloersen et al. 1992), the likelihood is that the satellite-derived ice concentrations are less accurate in summer than in the other three seasons, and indeed Steffen and Schweiger (1991) find greater differences between the SSM/I-derived ice concentrations and Landsat-derived ice concentrations in summer than in spring and fall. Specifically, using data from the Beaufort and Chukchi seas from 1987 and 1988 , they find the mean difference between ice concentrations derived from SSM/I data and those derived from Landsat data to be $0.6 \pm 7.4 \%$ in fall, $-2.1 \pm$ $3.1 \%$ in spring, and $11.0 \pm 22.9 \%$ in summer. In the Bering Sea in spring they find differences of $-9.4 \pm$ $6.1 \%$, and in the Greenland Sea in fall they find -3.7 $\pm 1.4 \%$ differences. Results are clearly dependent on location as well as time; and one study, by Emery et al. (1994), does not find the expected worsened accuracy in summer, reporting instead a $6 \%$ difference between ice concentrations derived from SSM/I data and those derived from data from the Advanced Very High Resolution Radiometer in nonsummer months and only a $3 \%$ difference in summer months. However, in spite of the variability both spatially and temporally, the $\pm 7 \%$ figure is considered a reasonable overall estimate for the accuracy of the passive-microwave data (Gloersen et al. 1992). It is anticipated that with the Advanced Microwave Scanning Radiometer (AMSR) planned for the Earth Observing System's Aqua satellite and the Japanese ADEOS II satellite, both scheduled for launch in 2001, the overall accuracies might be improved to $\pm 4 \%$, again with the expectation that the accuracies will be somewhat less in summer than in the other three seasons. Validation efforts planned for these missions should provide more complete seasonal and regional accuracy estimates within the next five years.

In this paper, we apply the GISS GCM to quantify that model's sensitivity to sea ice concentrations when run in the AMIP-type mode of specifying SSTs and other boundary conditions. We include runs with ice concentration changes of $\pm 7 \%$ and $\pm 4 \%$ specifically for their relevance to satellite accuracies, but we also include a broader range of ice concentration changes, to examine a wider variety of conditions and the linearity of the responses. In addition to quantifying the GISS GCM's sensitivity to sea ice concentrations, the results have implications for what the uncertainties in the sea ice records of the past few decades could mean regarding the model results and for what is to be gained by increasing the accuracy of the satellite sea ice retrievals from the current $\pm 7 \%$ to the anticipated $\pm 4 \%$. We caution, however, that in view of the specification of SSTs, these results alone cannot be used to determine the full effect of sea ice changes on climate, since specifying SSTs automatically limits the sea ice/albedo and other feedbacks. 


\section{Methodology}

\section{a. The model}

The model used for this study is the current version (version B224) of the atmospheric portion of the GISS GCM, which is updated from the version of the model used in our previous sea ice-sensitivity studies (Rind et al. 1995, 1997). Version B224 has been enhanced over the version of the GISS GCM described in Rind and Lerner (1996) and Hansen et al. (1997) by the single adjustment of applying ice albedos to ice surfaces and water albedos to water surfaces rather than applying the same area-weighted surface albedo to both the ice and water surfaces throughout a grid cell. Hence, we refer the reader to Rind and Lerner (1996) and Hansen et al. (1997) for more comprehensive descriptions of the model and concentrate our discussion here on the parameterizations most important for explaining the results in section 3 .

The model resolution is $4^{\circ}$ latitude by $5^{\circ}$ longitude, with nine layers in the atmosphere. While the grid is coarse, each grid cell is allowed to have varying percentages of land, ocean, and sea ice, hence allowing detailed changes in sea ice percentages. In each of the simulations, 1985 concentrations of trace gases (e.g., $345 \mathrm{ppm}$ for carbon dioxide) and estimated atmospheric aerosols are used, and SST fields are specified for each month from climatological SST datasets of Robinson and Bauer (1981). The temperature of the sea ice is calculated within the model, assuming two layers in the ice. The top ice layer is $10-\mathrm{cm}$ thick, overlain by snow of variable thickness, while the bottom ice layer thickness is a minimum of $10 \mathrm{~cm}$ and generally less than 6 $m$. The heat capacity and conductivity of the ice are uniform in each layer, while the temperature in each layer is a quadratic function of depth. At the undersurface of the bottom ice layer, the temperature of the ice is set at the ocean freezing point, that is, $-1.56^{\circ} \mathrm{C}$.

Heat is conducted upward from the ocean to the bottom ice layer, and from there to the top ice layer, before interacting with the atmosphere. Thinner ice therefore allows for greater heat loss, through the conductivity equations. In the experiments described here, we do not allow the thickness of the ice to vary from year to year (it varies spatially and day by day within the year), so as not to introduce an additional factor into the experiment. Snow cover alters the conductivity, heat capacity, and albedo of the surface layer directly in contact with the atmosphere. The specified snow-free sea ice albedo is 0.55 in the visible and 0.3 in the near infrared, for a spectrally weighted sea ice albedo of 0.45 . The spectrally integrated albedo of snow ranges from 0.85 to 0.50 , depending on its age and thickness (Hansen et al. 1983). As mentioned above, the snow, ice, and water albedos are applied to the individual surfaces, in contrast to the formulations in some earlier versions of the GISS GCM, in which the same weighted albedo over an entire grid cell was applied to each surface within the grid cell.

The surface air temperature is calculated by assuming that the heat flux from the ground (including sea ice or ocean surfaces) to a height of $30 \mathrm{~m}$ in the atmosphere is equal to the heat flux from the $30 \mathrm{~m}$ height to the rest of the atmospheric boundary layer. The drag coefficients for momentum, heat (the Stanton number), and moisture (the Dalton number) are functions of atmospheric stability and are calculated to determine the fluxes into the atmospheric surface layer from below. Stability-dependent transport coefficients associated with turbulent diffusion are used in the calculation of fluxes from the $30 \mathrm{~m}$ height to the higher levels of the atmospheric boundary layer. Similarity theory is used to compute the drag and transport coefficients (Hartke and Rind 1997). The surface air temperature generally lies between the ground temperature and the potential temperature of the bottom atmospheric layer (at a mean height of $200 \mathrm{~m}$ ), being numerically close to the ground temperature when the drag coefficient is much higher than the turbulent diffusivity and close to the potential temperature of the bottom atmospheric layer when the turbulent diffusivity dominates. Removal of sea ice in the presence of a cold atmosphere results in a greater surface-to-atmosphere temperature difference, hence increasing the drag coefficient and tending to force the surface air temperature closer to the sea surface temperature.

Clouds are calculated in the model using a cloud water budget parameterization described by Del Genio et al. (1996). Cloud optical thickness is calculated from the predicted water/ice path, and a variable droplet effective radius is estimated by assuming constant droplet number concentration. Reduction in moisture availability, as might arise with increased sea ice, will not only make clouds less likely but will produce clouds with smaller optical thickness. Where present, clouds are assumed to occupy an entire grid cell indiscriminately, with the cloud cover identical over all the fractional ground coverage types within the cell. The surface air temperature and surface fluxes, however, are calculated over the individual surface types.

\section{b. The sea ice input data}

The sea ice concentrations used as input for the model experiments were derived from the satellite radiative data recorded by the Nimbus-7 SMMR. The Nimbus-7 was launched in late October 1978, and the SMMR provided good quality data on an every-other-day basis for most of the period from 26 October 1978 to 20 August 1987. The SMMR was a 10-channel instrument, recording vertically and horizontally polarized radiation at five frequencies between 6.6 and $37 \mathrm{GHz}$. The radiative data were converted into sea ice concentrations using three of the channels (those obtaining horizontally and vertically polarized data at $18 \mathrm{GHz}$ and vertically 
TABLE 1. Global and hemispheric annually averaged percent sea ice coverages for each of the 17 simulations. These are calculated by summing the area of each grid element multiplied by its ice concentration, then dividing by the area of the region under consideration (the globe, Northern Hemisphere, or Southern Hemisphere, respectively).

\begin{tabular}{|c|c|c|c|c|c|c|c|}
\hline \multirow[b]{2}{*}{ Case } & \multicolumn{3}{|c|}{ Sea ice coverage (\%) } & \multirow[b]{2}{*}{ Case } & \multicolumn{3}{|c|}{ Sea ice coverage $(\%)$} \\
\hline & Global & N. Hemis. & S. Hemis. & & Global & N. Hemis. & S. Hemis. \\
\hline$-50 \%$ & 1.4 & 1.8 & 1.0 & $+50 \%$ & 5.8 & 6.0 & 5.6 \\
\hline$-40 \%$ & 1.8 & 2.2 & 1.3 & $+40 \%$ & 5.5 & 5.8 & 5.2 \\
\hline$-30 \%$ & 2.2 & 2.7 & 1.7 & $+30 \%$ & 5.2 & 5.5 & 4.9 \\
\hline$-20 \%$ & 2.7 & 3.2 & 2.2 & $+20 \%$ & 4.8 & 5.2 & 4.4 \\
\hline$-7 \%$ & 3.4 & 4.0 & 2.8 & $+7 \%$ & 4.2 & 4.8 & 3.7 \\
\hline$-4 \%$ & 3.6 & 4.1 & 3.0 & $+4 \%$ & 4.1 & 4.6 & 3.5 \\
\hline$-2 \%$ & 3.7 & 4.3 & 3.1 & $+2 \%$ & 3.9 & 4.5 & 3.4 \\
\hline$-1 \%$ & 3.7 & 4.3 & 3.1 & $+1 \%$ & 3.9 & 4.5 & 3.3 \\
\hline Control & 3.8 & 4.4 & 3.2 & Control & 3.8 & 4.4 & 3.2 \\
\hline
\end{tabular}

polarized data at $37 \mathrm{GHz}$ ) and an algorithm based on 1) polarization and gradient ratios created from the three data channels and 2) the assumption that the ocean surface is dominated by three surface types: water and two ice types. The resulting derived sea ice concentrations have a spatial resolution of approximately $55 \mathrm{~km}$ and an estimated overall accuracy of $\pm 7 \%$. Seasonally, summertime-derived ice concentrations are probably less accurate than the ice concentrations derived for winter, spring, and autumn (e.g., Steffen and Schweiger 1991), although, as mentioned in the introduction, not all studies have found that (e.g., Emery et al. 1994). Details on the SMMR instrument, on the two assumed ice types (multiyear and first-year ice in the Arctic; unspecified type A and type B ice in the Antarctic), and on the calculation of sea ice concentrations can be found in Gloersen et al. (1992). The SMMR ice concentration dataset is available on CD-ROM from the National Snow and Ice Data Center (NSIDC) in Boulder, Colorado.

For the current study, we took the average monthly ice concentrations throughout the period of full-year SMMR data coverage, 1979-86, regridded them to the grid of the GISS GCM, and used the regridded values as the assigned ice concentrations at the midpoint of each month in our control simulation. The assigned ice concentrations for all other days in the control case were linearly interpolated between the midpoints of consecutive months. The coarseness of the $4^{\circ} \times 5^{\circ}$ grid of the GISS GCM meant degrading the resolution from the grid of the ice concentration data, losing spatial resolution, but we retained the appropriately averaged sea ice concentrations.

Sea ice thicknesses were assigned, by grid point and month, as described in Rind et al. (1995) based on in situ observations. This annual cycle of ice thicknesses, like that of ice concentrations, was held constant during the course of each simulation.

\section{c. The simulations}

To examine the effect of ice concentrations and ice concentration accuracies on the simulated climate, we ran the GISS GCM for 17 seven-yr simulations. All initializing and other assigned conditions except sea ice concentrations are identical in each of the simulations. The distinctions in assigned ice concentrations among the 17 simulations are the following.

- The control case has realistic daily sea ice concentration fields derived from the SMMR satellite passivemicrowave data, as described in section $2 \mathrm{~b}$, although with an upper limit of $99.5 \%$ ice concentration. The upper limit forces at least $0.5 \%$ lead area within each grid cell, thereby allowing some direct ocean/atmosphere contact within each cell.

- The $+7 \%$ case has all the assigned sea ice concentrations, in each grid cell and each time period, uniformly increased by $7 \%$ over their values in the control case, with the two exceptions that 1) $0 \%$ ice concentration remains at $0 \%$ and 2) incremented ice concentrations that exceed $99.5 \%$ are capped at $99.5 \%$. The increase is additive; for example, $40 \%$ ice concentration is increased to $47 \%$ ice concentration. The 99.5\% cap prevents the geophysically impossible situation of ice concentrations exceeding $100 \%$ and forces at least $0.5 \%$ lead area within each grid cell.

- The $-7 \%$ case has all the assigned sea ice concentrations, in each grid cell and each time period, uniformly decreased by 7\% (again additively) below their values in the control case. Any ice concentrations thereby decreased to below $0 \%$ are set at $0 \%$.

- The ice concentration fields in the $+1 \%,+2 \%,+4 \%$, $+20 \%,+30 \%,+40 \%$, and $+50 \%$ cases are each constructed identically to the $+7 \%$ case, although with $1 \%, 2 \%, 4 \%, 20 \%, 30 \%, 40 \%$, and $50 \%$ ice concentration increases rather than $7 \%$ increases.

- The ice concentration fields in the $-1 \%,-2 \%,-4 \%$, $-20 \%,-30 \%,-40 \%$, and $-50 \%$ cases are each constructed identically to the $-7 \%$ case, although with $1 \%, 2 \%, 4 \%, 20 \%, 30 \%, 40 \%$, and $50 \%$ ice concentration decreases rather than $7 \%$ decreases.

Neither the addition nor the subtraction of ice alters the assigned ice thicknesses in the grid cells. Further- 
more, during the simulations, all sea ice specifications remain constant from year to year, while varying from month to month. Table 1 presents the resulting annually averaged sea ice coverage specifications for the globe, the Northern Hemisphere, and the Southern Hemisphere for each of the model runs, taking into account the spatial variations, the $0 \%$ lower and $99.5 \%$ upper limits on ice coverages in each grid cell, and the fact that grid cells with $0 \%$ ice coverage in the control run stay at $0 \%$ ice coverage in each of the runs.

Because the model has specified rather than calculated oceanic conditions, with no interannual variations in SST or other ocean variables (SSTs do vary within the year), stabilization was rapid, as expected from Rind (1998), and in each simulation the results were close for each year after year 2. For instance, in the control run the yearly average global surface air temperatures varied by only $0.11^{\circ} \mathrm{C}$, from $13.53^{\circ}$ to $13.64^{\circ} \mathrm{C}$, over the simulation years 3-7 (and, in fact, over the years 3-14 when the control case was run out further for test purposes). Previous experience with the GISS GCM has indicated the appropriateness of using 5-yr results from the GISS GCM when the simulations are constrained by specified SSTs (Rind 1998). Consequently, the simulations were each run for just seven years, with the results being averaged for the final five years, that is, years 3-7. These averaged results were used to examine the temperature and radiative responses of the model and energy budgets at the ground and in the atmosphere.

By varying the sea ice concentrations identically in each grid cell, we are directly investigating the effects of a bias in the specified sea ice fields rather than random variations. This will tend to maximize the temperature response, as not only is the locally induced change of a given sign, but the advective change from upwind will often be of the same sign as well, and when examined on a large spatial scale, the uniformity of sign in the sea ice changes will prevent the cancellation of positive and negative responses that would be expected with random variations. Although errors in satellite retrievals are likely to be largely random (known biases would be removed), biases may be involved, for instance if very thin ice is underestimated, as suggested by the results of Steffen and Schweiger (1991). Biases may also be associated with the AMIP sea ice dataset, as indicated by Hansen et al. (1997), who find an excessive warming using the AMIP boundary conditions and suggest that this could be due to systematic errors in the sea ice conditions. Furthermore, most modeling experiments for future climate change assessments simulate a widespread reduction in sea ice, not random increases and decreases. The results in section 3 provide an indication of what might be expected, at least from the GISS GCM, due exclusively to local changes in sea ice of the same sign, without global feedbacks.

\section{Results}

a. Atmospheric temperatures for cases within the range of estimated satellite-derived sea ice concentration uncertainties

In general, the expectation is that, locally at least, increased sea ice concentrations will lead to lower surface air temperatures and decreased sea ice concentrations will lead to higher temperatures, largely due to two effects: 1) more solar radiation gets reflected away from the surface and back to space in the presence of higher ice concentrations, because of the much higher shortwave albedo of ice than of water; and 2) less heat gets transferred from the ocean to the atmosphere in the presence of more ice, because the ice serves as an effective insulator (Parkinson et al. 1987). Impacts distant from the ice cover are not as readily predicted, because of the intricacies possible with the changed atmospheric circulation patterns resulting from the temperature changes in the polar regions. These impacts, moreover, in our simulations are reduced because of the use of specified rather than simulated SSTs.

Figure 1 shows the mapped differences, by month, of the monthly average surface air temperatures as simulated with sea ice concentrations increased by $7 \%$ $(+7 \%$ case $)$ versus as simulated in the control case. Stippling indicates regions where the absolute value of the mapped differences divided by the respective 5-yr (yr 3-7) standard deviations in the control case exceeds two. Equivalently, stippling indicates regions where the $+7 \%$ case has temperatures at least two standard deviations away from the value in the control case, providing a local signal-to-noise ratio indication of statistical significance at the $95 \%$ level.

Air temperatures are affected by the $7 \%$ ice concentration increases throughout the globe and in all months, although the largest effects tend to occur during fall and winter in the polar regions (Fig. 1). In the north polar region, the month most affected is the winter month of January, when much of the Arctic shows a cooling exceeding $4^{\circ} \mathrm{C}$ as a result of the increased sea ice concentrations in the $+7 \%$ case. In the south polar region, the winter months, July-September, are all comparably affected, with cooling of $2^{\circ} \mathrm{C}$ or more over much of the ice-covered region of the Southern Ocean. Outside the polar regions, the temperature impacts of the $7 \%$ increase in sea ice concentrations tend, by and large, to be less than $1^{\circ} \mathrm{C}$, undoubtedly aided by the unchanging SST annual cycle. Notably, some areas both of the polar regions and of the nonpolar regions show temperature increases rather than decreases, a phenomenon associated with altered advection patterns due to the pressure gradients set up in the regions of sea ice change. Temperature increases are particularly prominent, with magnitudes of $2^{\circ}-4^{\circ} \mathrm{C}$, over portions of Antarctica in the June-September time frame, over Greenland in February and October, in Europe in May and July, in Australia in April and December, and in the eastern and 


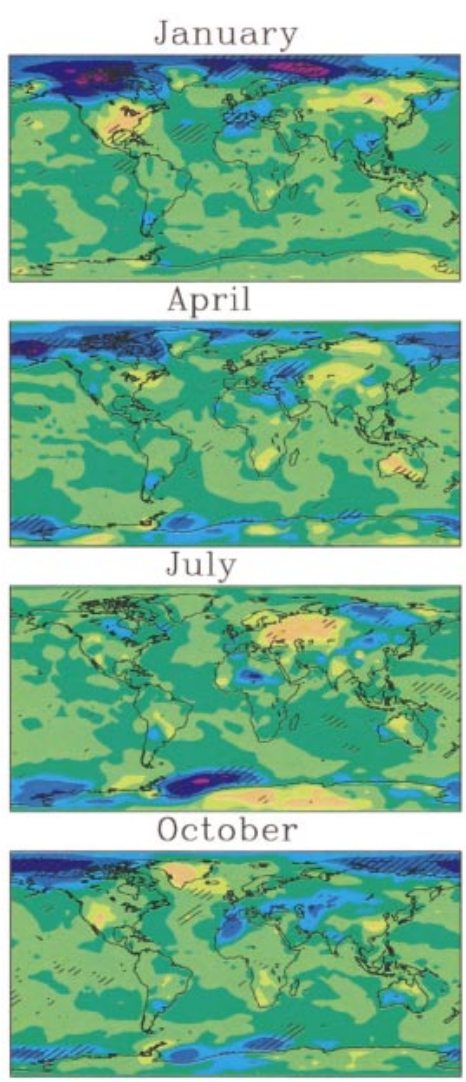

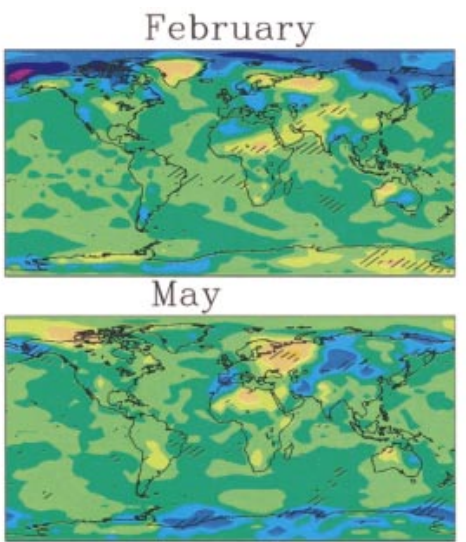

August

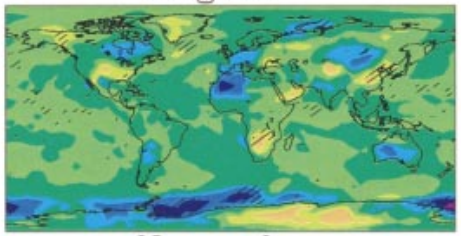

November

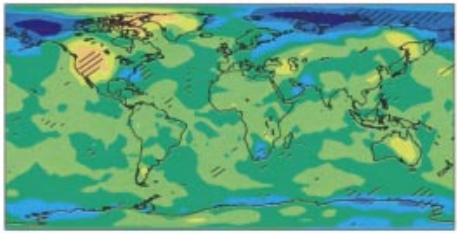

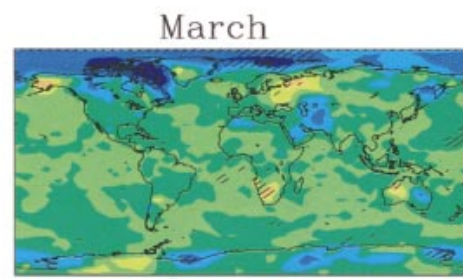

June

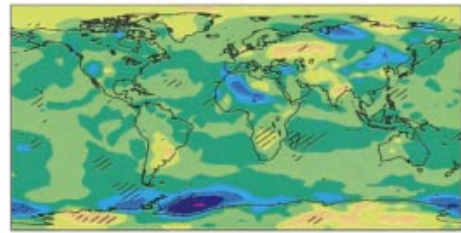

September

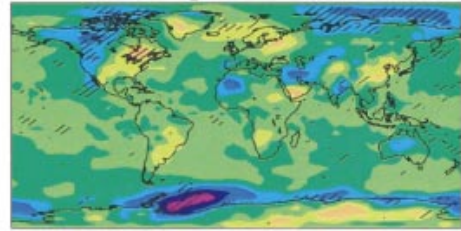

December

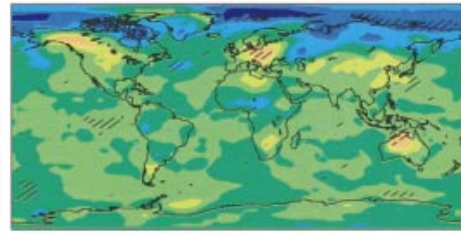

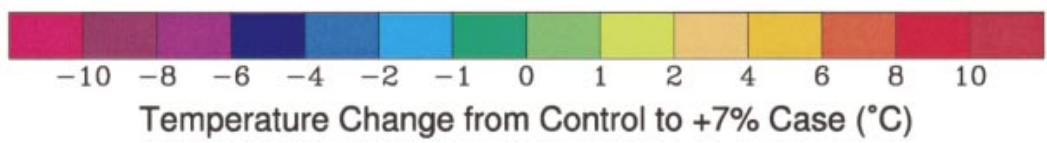

FIG. 1. Differences (in ${ }^{\circ} \mathrm{C}$ ) between the monthly average surface air temperatures simulated in the case with all ice concentrations increased by $7 \%$ and those simulated in the control case ( $+7 \%$ results minus control results). Stippling indicates regions in which the absolute magnitude of the value divided by the interannual standard deviation in the control case exceeds 2 , suggesting statistical significance at the $95 \%$ confidence level.

western United States in January and November, respectively (Fig. 1). On average, however, the temperature increases are outweighed by the temperature decreases, with globally averaged temperatures reduced by $0.10^{\circ} \mathrm{C}$ (from $13.57^{\circ}$ to $13.47^{\circ} \mathrm{C}$ ) and hemispherically averaged temperatures reduced by $0.14^{\circ}$ and $0.07^{\circ} \mathrm{C}$ in the Northern and Southern Hemispheres, respectively, all as a result of the $7 \%$ ice concentration increases (Table 2). It is clear that although globally and hemispherically averaged temperatures decrease only slightly (Table 2), the uniform ice concentration increases of $7 \%$ make a difference exceeding $6^{\circ} \mathrm{C}$ in the simulation of

TABLE 2. Global and hemispheric annually averaged surface air temperatures for each of the 17 simulations. All results are averaged over years 3-7 of the respective model runs.

\begin{tabular}{|c|c|c|c|c|c|c|c|}
\hline \multirow[b]{2}{*}{ Case } & \multicolumn{3}{|c|}{ Surface air temperature $\left({ }^{\circ} \mathrm{C}\right)$} & \multirow[b]{2}{*}{ Case } & \multicolumn{3}{|c|}{ Surface air temperature $\left({ }^{\circ} \mathrm{C}\right)$} \\
\hline & Global & N. Hemis. & S. Hemis. & & Global & N. Hemis. & S. Hemis. \\
\hline$-50 \%$ & 14.11 & 15.22 & 12.99 & $+50 \%$ & 13.18 & 14.19 & 12.18 \\
\hline$-40 \%$ & 14.07 & 15.20 & 12.95 & $+40 \%$ & 13.25 & 14.26 & 12.23 \\
\hline$-30 \%$ & 14.03 & 15.11 & 12.96 & $+30 \%$ & 13.26 & 14.23 & 12.29 \\
\hline$-20 \%$ & 13.91 & 14.97 & 12.84 & $+20 \%$ & 13.32 & 14.26 & 12.39 \\
\hline$-7 \%$ & 13.74 & 14.75 & 12.73 & $+7 \%$ & 13.47 & 14.41 & 12.53 \\
\hline$-4 \%$ & 13.68 & 14.66 & 12.71 & $+4 \%$ & 13.50 & 14.44 & 12.55 \\
\hline$-2 \%$ & 13.63 & 14.61 & 12.66 & $+2 \%$ & 13.54 & 14.46 & 12.61 \\
\hline$-1 \%$ & 13.61 & 14.56 & 12.66 & $+1 \%$ & 13.60 & 14.57 & 12.63 \\
\hline Control & 13.57 & 14.55 & 12.60 & Control & 13.57 & 14.55 & 12.60 \\
\hline
\end{tabular}


January

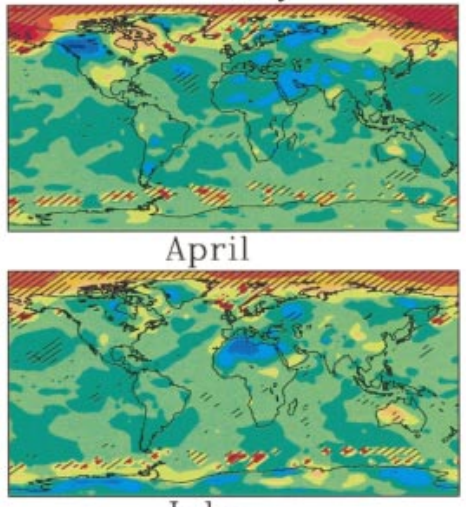

July

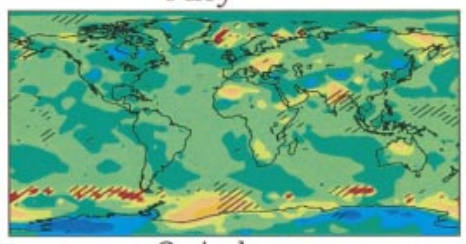

October

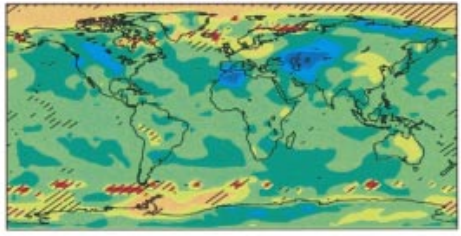

February

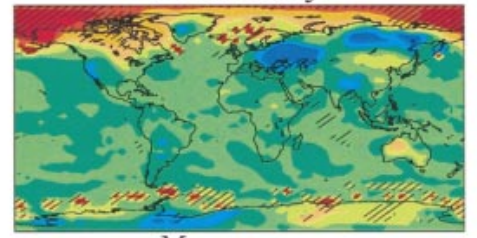

May

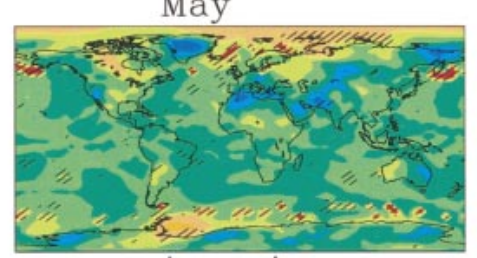

August

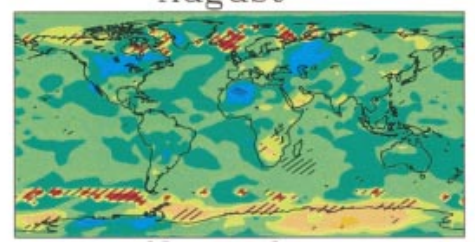

November

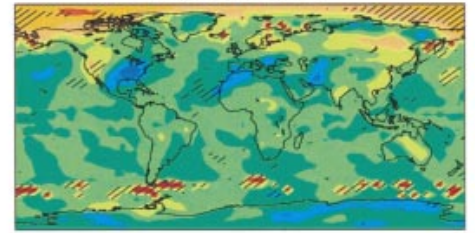

March

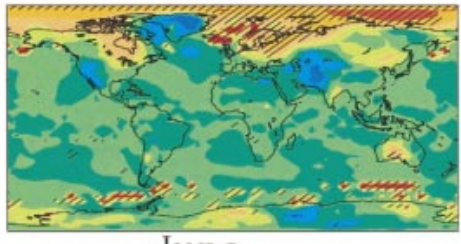

June

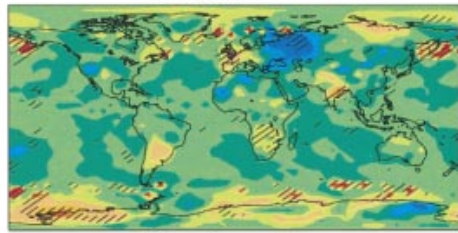

September

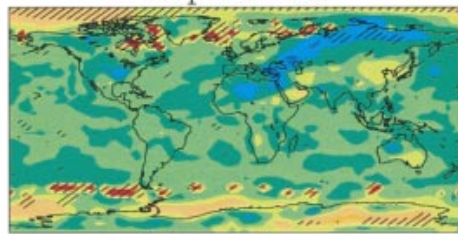

December

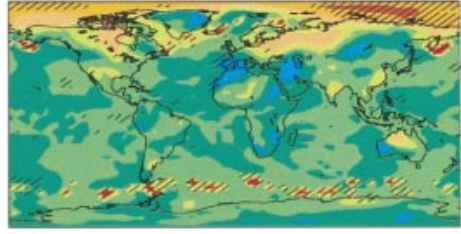

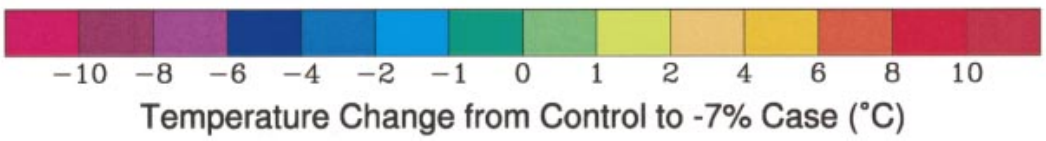

FIG. 2. Same as Fig. 1 except for the $-7 \%$ results minus the control results.

some atmospheric temperatures when viewed geographically and on a monthly average basis (Fig. 1).

In the opposite case, with ice concentrations uniformly decreased by $7 \%$ ( $-7 \%$ case), globally averaged surface air temperatures are increased by $0.17^{\circ} \mathrm{C}$ over those in the control case and Northern and Southern Hemisphere temperatures are increased by $0.20^{\circ}$ and $0.13^{\circ} \mathrm{C}$, respectively, over those in the control case (Table 2). Spatially, Fig. 2 shows the mapped differences, by month, of the temperatures simulated in the $-7 \%$ case versus those simulated in the control case. The strongest temperature increases are in the Arctic in winter, with temperature increases exceeding $6^{\circ} \mathrm{C}$ over the majority of the Arctic Ocean in both January and February. Over the Southern Ocean, temperature increases above $4^{\circ} \mathrm{C}$ tend to be scattered and localized, although in some of these scattered locations the increases exceed $8^{\circ} \mathrm{C}$ (Fig. 2). The months with the largest cohesive areas of Southern Hemisphere temperature increases above $4^{\circ} \mathrm{C}$ are the late fall and winter months of June-September. Some of the polar land regions, in particular the Antarctic continent in July and Greenland in March and May, show prominent temperature decreases in spite of the decreased sea ice coverage (Fig. 2). Lower pressure in these areas associated with the warmer temperatures and reduced atmospheric stability over the former sea ice fields incites a cyclonic circulation, and where the air comes preferentially from higher latitudes, colder temperatures result.

The magnitudes of the simulated temperature changes versus the control case are comparable for the $-7 \%$ and $+7 \%$ cases, although both hemispheres overall are more affected by ice concentration decreases than by ice concentration increases (Table 2; Figs. 1-2). This is partly because of the upper limit on ice concentrations $(99.5 \%$ in our specifications, although the geophysical $100 \%$ limit would act similarly), preventing the full $7 \%$ additive increase from being applied wherever the ice concentration in the control run exceeds $92.5 \%$, a situation that occurs especially in the central Arctic. The capping of the ice concentrations also helps explain why the largest temperature response in the Northern Hemisphere in the $+7 \%$ case is in many months somewhat equatorward of the pole (Fig. 1). In contrast, in the $-7 \%$ case, the full $7 \%$ decrease is applied throughout the 
central Arctic, enhancing the temperature response in that region.

The Southern Hemisphere temperature response is in general smaller than the response in the Northern Hemisphere (Figs. 1-2; Table 2). Southern Hemisphere sea ice changes occur at a lower latitude, with lower atmospheric stability, so that warming and moisture are not as trapped at low levels, diffusing the surface air temperature response and limiting to some extent the low-level cloud-radiative feedback.

On a globally or hemispherically averaged basis, the surface air temperature results for the intermediate cases $(+4 \%,+2 \%,+1 \%$, control case, $-1 \%,-2 \%,-4 \%)$ lie between those for the $+7 \%$ and $-7 \%$ cases, although the relationship is not strictly uniform (Table 2). Specifically, although both hemispheres show the expected increase in temperatures from the $+7 \%$ to the $+4 \%$ to the $+2 \%$ to the $+1 \%$ case, both hemispheres also have an anomaly in that the $+1 \%$ surface air temperatures exceed the control values (Table 2). Still, the general trend for each hemisphere and globally is for the air temperatures to increase in response to each decrease in ice concentrations (Table 2).

Addressing specifically the issue of the possible improvement in satellite-derived sea ice concentration accuracies from $\pm 7 \%$ for the current SSM/I instruments to $\pm 4 \%$ for the upcoming AMSR instrument, the numbers in Table 2 can be viewed as providing the extreme temperature impacts in specified-SST experiments for the respective cases. Since uncertainties associated with satellite retrievals are likely a mixture of random and systematic uncertainties, they would likely produce smaller overall temperature variations in AMIP-type simulations than the biases employed here, where all concentrations are uniformly increased or decreased by the same amount. With that in mind, Table 2 suggests that the improvement from $\pm 7 \%$ to $\pm 4 \%$ in ice concentrations would reduce by about a third the resulting extreme-case surface air temperature uncertainties. Globally, the simulated air temperature range would be narrowed from $13.47^{\circ}-13.74^{\circ} \mathrm{C}$ for the $\pm 7 \%$ ice uncertainties to $13.50^{\circ}-13.68^{\circ} \mathrm{C}$ for the $\pm 4 \%$ ice uncertainties, that is, narrowing from a $0.27^{\circ}$ to a $0.18^{\circ} \mathrm{C}$ range in induced air temperature uncertainties. Where sea ice datasets have produced biased trend estimates, a reduction of this magnitude would provide significant improvement in global surface air temperature reconstructions. Hemispherically, the improvement in satellite accuracies from $\pm 7 \%$ to $\pm 4 \%$ would narrow the simulated Northern Hemisphere induced temperature uncertainties from $0.34^{\circ}$ to $0.22^{\circ} \mathrm{C}$ and the simulated Southern Hemisphere induced temperature uncertainties from $0.20^{\circ}$ to $0.16^{\circ} \mathrm{C}$ (Table 2).

\section{b. Atmospheric temperatures for a wider range of sea ice variations}

Considering now a wider range of sea ice concentration variations, the general trend for each hemisphere

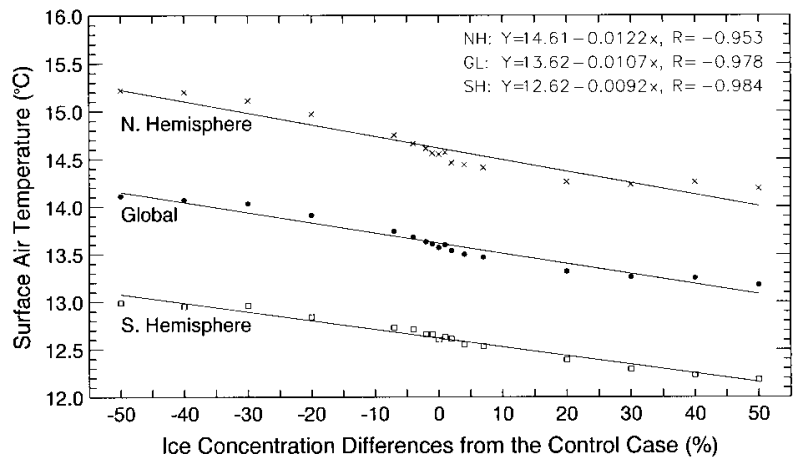

FIG. 3. Global and hemispheric annually averaged surface air temperatures (in ${ }^{\circ} \mathrm{C}$ ) for each of 17 simulations, with lines of linear leastsquares fit through the global, Northern Hemisphere, and Southern Hemisphere values. All values are averaged over the five simulation years 3-7 and are listed in Table 2. Least squares fit equations are shown for each of the three lines, along with the corresponding linear correlation coefficients ( $R$ values).

and the globe remains for the air temperatures to increase in response to each decrease in ice concentrations (Table 2). The relationship between simulated average air temperatures and the magnitude of the assigned ice concentration differences is approximately linear, and the slopes of the lines of linear least squares fit indicate, on average, yearly average global surface air temperature decreases of $0.011^{\circ} \mathrm{C}$ for every $1 \%$ ice concentration increase and yearly average Northern and Southern Hemisphere surface air temperature decreases of $0.012^{\circ}$ and $0.009^{\circ} \mathrm{C}$, respectively, for every $1 \%$ ice concentration increase (Fig. 3).

Figure 4 presents the mapped February surface air temperature differences between eight of the noncontrol cases and the control case, and Fig. 5 presents the corresponding August maps. In both figures, stippling gives an indication of statistical significance, as in Figs. 1-2. In February, in the midst of the Northern Hemisphere winter, the impact of the ice concentration changes is greatest in the Arctic and generally small $\left(<1^{\circ} \mathrm{C}\right)$ in the tropical regions and over the ice-free oceans. In the Arctic, as ice concentration increases rise from $4 \%$ to $50 \%$, the temperature decreases fairly systematically, except immediately north of Alaska and western Canada, where the greatest temperature decrease occurs in the $+20 \%$ case rather than in the $+50 \%$ case. Temperature decreases over the Arctic Ocean average about $5^{\circ} \mathrm{C}$ for both the $+20 \%$ and the $+50 \%$ cases. As ice concentration decreases go from $-4 \%$ to $-50 \%$, the temperature increases in the Arctic are even more systematic and considerably stronger than the temperature decreases in the enhanced ice concentration cases. Temperature increases exceed $10^{\circ} \mathrm{C}$ for most of the Arctic for ice concentration decreases of $20 \%$ and for an even larger percentage of the Arctic for ice concentration decreases of $50 \%$ (Fig. 4). The greater impact of the ice concentration decreases versus the ice concentration increases results in part from the fact that over much of 


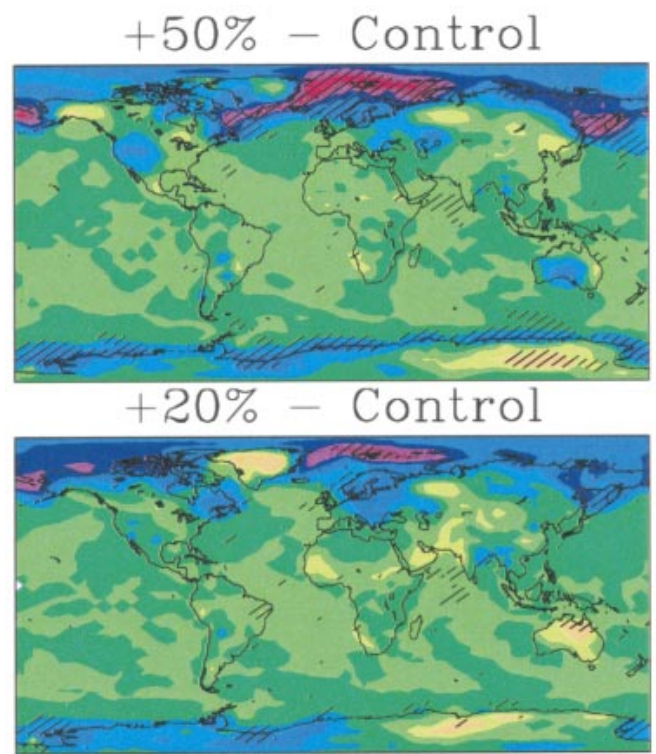

$+7 \%$ - Control

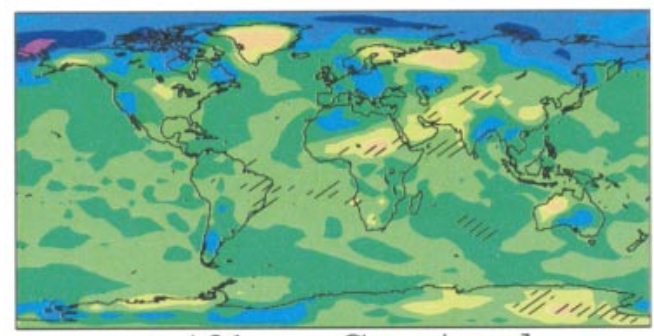

$+4 \%$ - Control

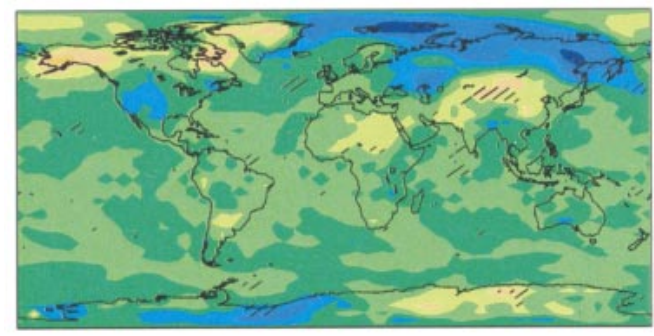

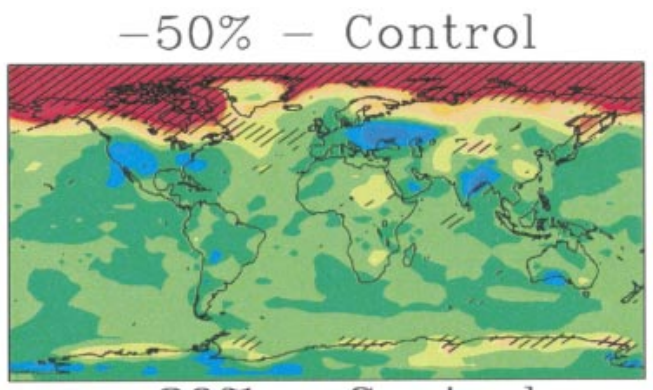

$-20 \%$ - Control

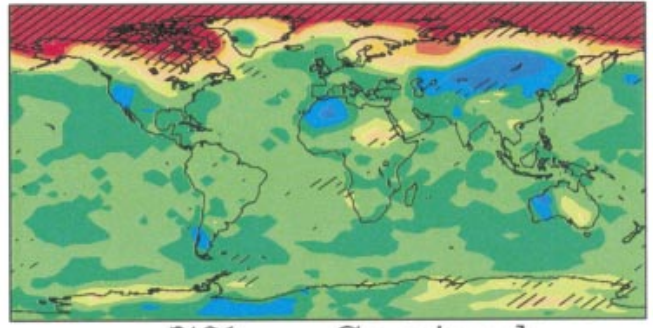

$-7 \%$ - Control

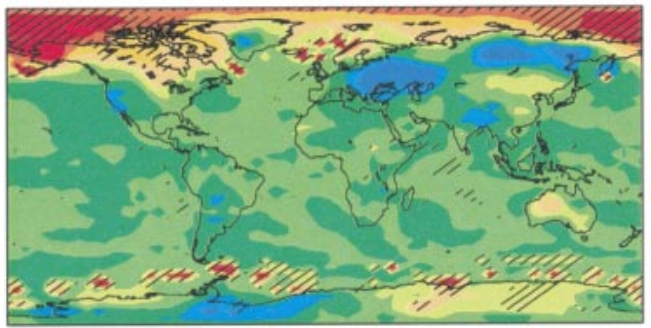

$$
-4 \% \text { - Control }
$$

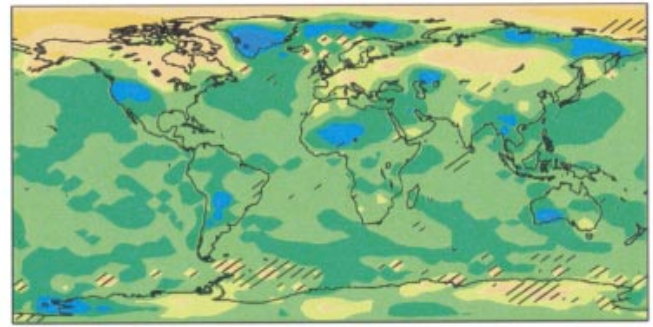

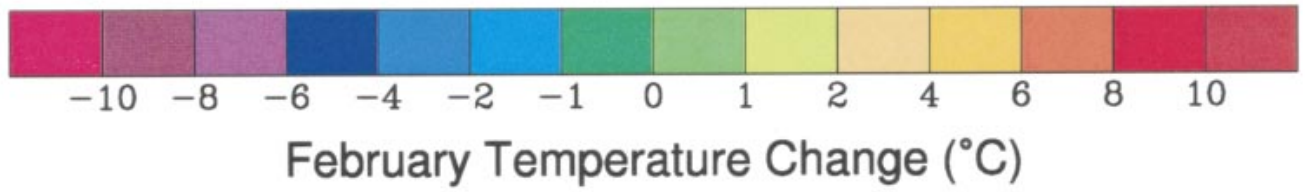

Fig. 4. Differences (in ${ }^{\circ} \mathrm{C}$ ) between the average Feb surface air temperatures simulated in eight of the noncontrol cases ( $\pm 4 \%, 7 \%, 20 \%$, and 50\%) and those simulated in the control case. Stippling indicates regions in which the absolute magnitude of the value divided by the interannual standard deviation of the Feb values in the control case exceeds 2, suggesting statistical significance at the 95\% confidence level.

the expanse of the February Arctic ice cover the ice concentration in the control case is high enough that, for example, additions of $20 \%$ and $50 \%$ result in the same capped value of $99.5 \%$ ice concentration.

In August, in the midst of the Southern Hemisphere winter, temperature impacts of the ice concentration changes tend to be greatest in the region of the Southern Ocean ice pack (Fig. 5). As in February, the changes from case to case are fairly systematic, with temperature decreases increasing for greater magnitude ice concentration increases and temperature increases increasing for greater magnitude ice concentration decreases. In the extreme cases, for ice concentration increases of 50\% the August temperature decreases over the Southern Ocean are generally in the range of $-4^{\circ}$ to $-10^{\circ} \mathrm{C}$, and for ice concentration decreases of $50 \%$ the tem- 


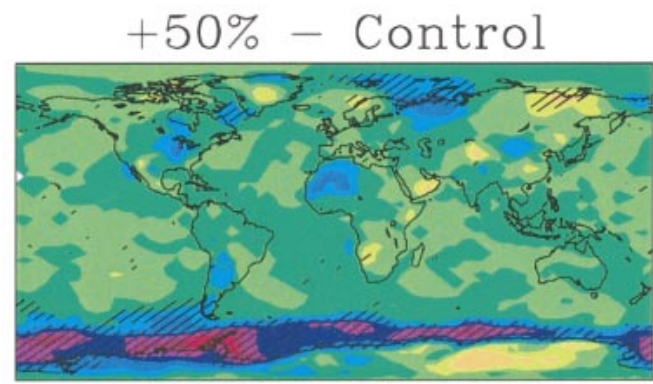

$+20 \%-$ Control

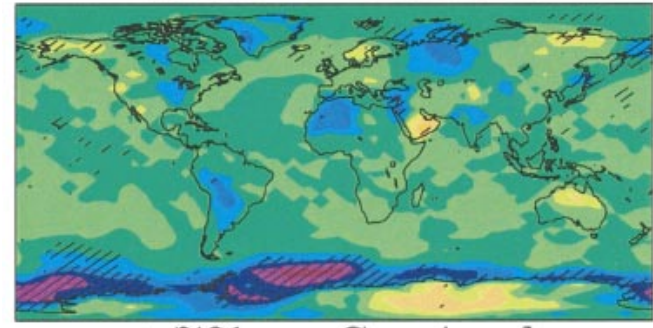

$+7 \%-$ Control

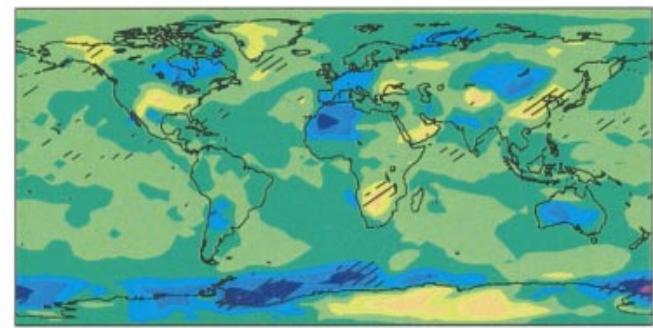

$+4 \%-$ Control

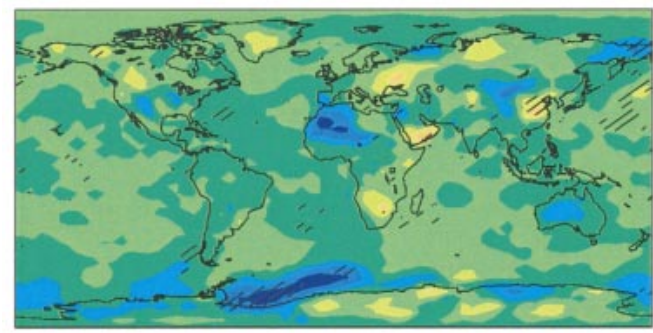

$-50 \%-$ Control

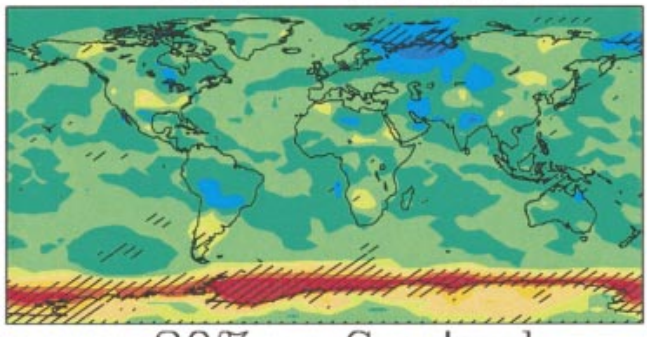

$-20 \%$ - Control

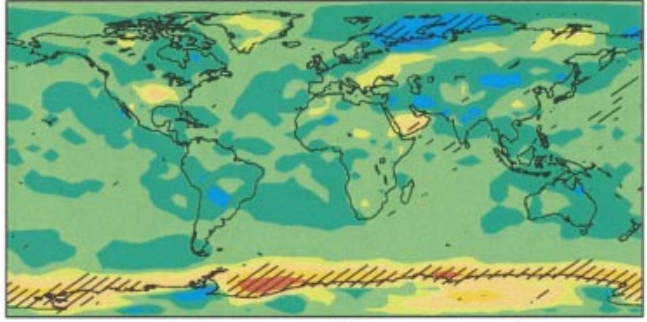

$-7 \%$ - Control

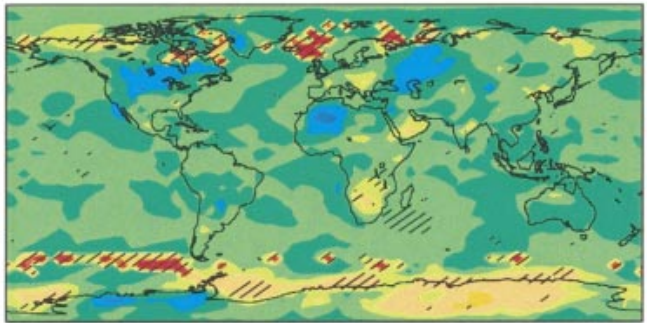

$-4 \%$ - Control

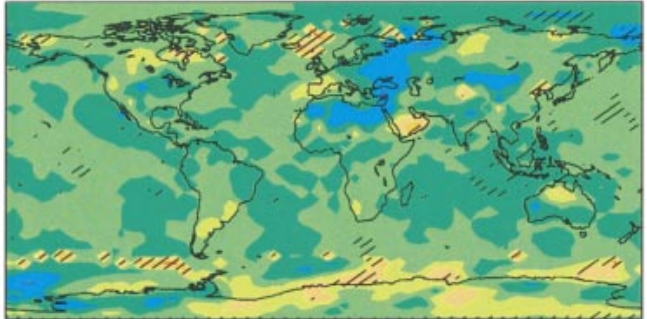

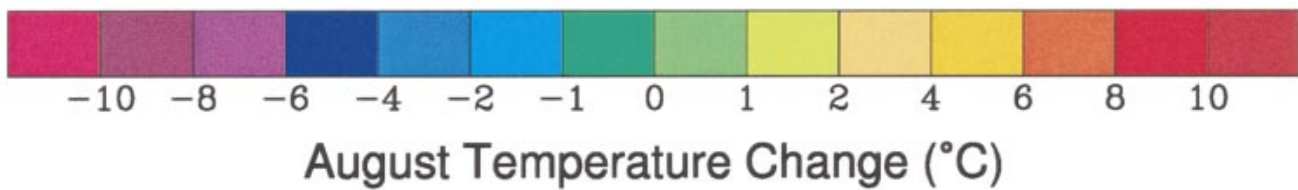

FIG. 5. Same as Fig. 4 except for Aug.

perature increases over the Southern Ocean generally exceed $6^{\circ} \mathrm{C}$, with a sizable area of the Weddell Sea exhibiting increases exceeding $10^{\circ} \mathrm{C}$ (Fig. 5). Temperature impacts at low latitudes tend to be small $\left(<1^{\circ} \mathrm{C}\right)$, although in scattered locations there are larger impacts $\left(2^{\circ}-4^{\circ} \mathrm{C}\right)$. This is noticeable both in northwest Africa, where temperature decreases exceeding $2^{\circ} \mathrm{C}$ appear in five of the eight cases of Fig. 5, and in southern Saudi Arabia, where temperature increases exceeding $2^{\circ} \mathrm{C}$ ap- pear in seven of the eight cases (Fig. 5). In both these regions the changes are not systematic and are not statistically significant (Fig. 5). Clearly modeling studies examining effects of high latitude ice/snow changes on tropical land areas via a monsoon connection need to consider the inherent variability of the region.

The change normalized by the standard deviation shows that, in general, the surface air temperature response is significant (differences greater than two stan- 
TABLE 3. Selected Feb results in the $-7 \%$ and $+7 \%$ simulations, averaged over the latitude band $80^{\circ}-84^{\circ} \mathrm{N}$, for sea ice portions of the grid cells (ice), liquid ocean portions (Oc), and the combined ice and liquid ocean portions ( $+\mathrm{O})$. In the case of fluxes, a positive value represents a gain of energy for the surface in question.

\begin{tabular}{|c|c|c|c|c|c|c|}
\hline & \multicolumn{3}{|c|}{$-7 \%$ case } & \multicolumn{3}{|c|}{$+7 \%$ case } \\
\hline & Ice & Oc & $\mathrm{I}+\mathrm{O}$ & Ice & $\mathrm{Oc}$ & $\mathrm{I}+\mathrm{O}$ \\
\hline Coverage $(\%)$ & 73.0 & 11.3 & 84.3 & 82.0 & 2.3 & 84.3 \\
\hline Vertically integrated air temperature $\left({ }^{\circ} \mathrm{C}\right)$ & -44.0 & -44.2 & -44.0 & -45.2 & -45.2 & -45.2 \\
\hline First-layer air temperature $\left({ }^{\circ} \mathrm{C}\right)$ & -24.5 & -23.6 & -24.4 & -33.8 & -30.1 & -33.7 \\
\hline Surface air temperature $\left({ }^{\circ} \mathrm{C}\right)$ & -26.2 & -18.6 & -25.2 & -35.0 & -24.0 & -34.7 \\
\hline Ocean/ice ground temperature $\left({ }^{\circ} \mathrm{C}\right)$ & -30.9 & -1.3 & -26.9 & -39.2 & -1.2 & -38.2 \\
\hline Second-layer ice temperature $\left({ }^{\circ} \mathrm{C}\right)$ & -8.8 & NA & NA & -11.9 & NA & NA \\
\hline Atmospheric water vapor (mm) & 1.2 & 1.2 & 1.2 & 1.0 & 1.0 & 1.0 \\
\hline Precipitation $\left(\mathrm{mm}\right.$ day $\left.^{-1}\right)$ & 0.4 & 0.5 & 0.41 & 0.3 & 0.4 & 0.30 \\
\hline Low clouds $(\%)$ & 63.9 & 63.9 & 63.9 & 56.8 & 60.8 & 56.9 \\
\hline Lowest layer cloud liquid water (ppmm) & NA & NA & 16 & NA & NA & 7 \\
\hline Middle clouds (\%) & 10.6 & 10.6 & 10.6 & 12.0 & 12.0 & 12.0 \\
\hline High clouds $(\%)$ & 0.5 & 0.5 & 0.5 & 0.5 & 0.5 & 0.5 \\
\hline Total cloud cover $(\%)$ & 71 & 71 & 71 & 65 & 69 & 65.1 \\
\hline Static stability (potential temperature ${ }^{\circ} \mathrm{km}^{-1}$ ) & 7.8 & 7.7 & 7.8 & 8.7 & 8.2 & 8.7 \\
\hline Shortwave radiation incident at surface $\left(\mathrm{W} \mathrm{m}^{-2}\right)$ & 0 & 0 & 0 & 0 & 0 & 0 \\
\hline Longwave radiation incident at surface $\left(\mathrm{W} \mathrm{m}^{-2}\right)$ & 169 & 172 & 169 & 143 & 155 & 143 \\
\hline Longwave radiation outgoing at surface $\left(\mathrm{W} \mathrm{m}^{-2}\right)$ & -194 & -307 & -209 & -170 & -309 & -174 \\
\hline Net longwave radiation at surface $\left(\mathrm{W} \mathrm{m}^{-2}\right)$ & -25 & -135 & -40 & -27 & -154 & -31 \\
\hline Net radiation at surface $\left(\mathrm{W} \mathrm{m}^{-2}\right)$ & -25 & -135 & -40 & -27 & -154 & -31 \\
\hline Sensible heat flux $\left(\mathrm{W} \mathrm{m}^{-2}\right)$ & 13 & -247 & -22 & 11 & -346 & 1 \\
\hline Evaporative heat flux $\left(\mathrm{W} \mathrm{m}^{-2}\right)$ & 1 & -87 & -11 & 0 & -99 & -3 \\
\hline Precipitation heat flux $\left(\mathrm{W} \mathrm{m}^{-2}\right)$ & -2 & -2 & -2 & -1 & -2 & -1 \\
\hline Net turbulent flux at surface $\left(\mathrm{W} \mathrm{m}^{-2}\right)$ & 12 & -336 & -35 & 10 & -446 & -3 \\
\hline Net heat at surface $\left(\mathrm{W} \mathrm{m}^{-2}\right)$ & -13 & -471 & -75 & -17 & -600 & -34 \\
\hline Upward heat flux from bottom ice layer $\left(\mathrm{W} \mathrm{m}^{-2}\right)$ & 11 & NA & NA & 16 & NA & NA \\
\hline
\end{tabular}

ppmm $=$ parts per million by mass; $\mathrm{NA}=$ not available.

dard deviations) in substantial areas of the Arctic in February and of the Antarctic in August beginning at about the $-7 \%$ and $+20 \%$ ice concentration levels (Figs. 4-5). Even with sea ice concentration changes on the order of $50 \%$, most of the temperature differences outside the polar regions are not significant, although in all of the noncontrol cases there are some scattered regions in low latitudes with results indicating statistical significance (Figs. 4-5). Of course by muting the temperature responses outside the polar regions, keeping the SSTs identical in each simulation lessens the possibility of significant responses.

\section{c. Analysis of the temperature response at high northern latitudes}

The results presented in Figs. 1-2 and 4-5 indicate relatively high sensitivity locally to changes in sea ice concentration, in spite of the absence of any feedbacks through changes in SST, the annual cycle of which was held constant. The surface air temperature change is a function of many factors, including the magnitude of the sea ice change (which, in view of the $0 \%$ and $99.5 \%$ lower and upper limits on sea ice concentrations, in some locations is not as large as the assigned increase or decrease for the particular simulation), the static stability of the atmosphere, the contrast between the ocean and air temperatures, and the shortwave radiation in- cident on the surface. In this section we present an analysis of the temperature changes, concentrating, for illustrative purposes, on the latitude zone $80^{\circ}-84^{\circ} \mathrm{N}$ and the $\pm 7 \%$ simulations. Tables $3-4$ present the zonally averaged February and August results for parameters relevant to the surface temperature changes in the $\pm 7 \%$ runs, averaged over the five simulation years $3-7$. Results are given for the sea ice portion of the latitude zone, the ocean portion, and the sea ice and ocean portions combined. As indicated in the first data row of Tables 3 and 4, sea ice and ocean together constitute $84.3 \%$ of the latitude zone. Table 5 presents the energy budgets for the vertically integrated atmosphere at $80^{\circ}-$ $84^{\circ} \mathrm{N}$ for both February and August.

Winter results, $80^{\circ}-84^{\circ} \mathrm{N}$. This section presents the $80^{\circ}-84^{\circ} \mathrm{N}$ zonal average February temperature results and an analysis of the factors causing the temperature differences. The surface air temperature is approximately $9^{\circ} \mathrm{C}$ warmer in the $-7 \%$ case than in the $+7 \%$ case, whether considering the values over sea ice alone or weighted over sea ice plus ocean (Table 3). The weighted ocean/ice ground temperature, weighting the temperature in the top layer $(10 \mathrm{~cm})$ of sea ice and the SST over the ice-free ocean, shows a comparable but slightly larger difference $\left(11.3^{\circ} \mathrm{C}\right)$, this latter difference deriving from both the colder ice surface in the $+7 \%$ case and the greater ice coverage. Specifically, from the numbers in Table 3, the weighted ground temperature 
TABle 4. Same as Table 3 except for Aug rather than Feb.

\begin{tabular}{|c|c|c|c|c|c|c|}
\hline & \multicolumn{3}{|c|}{$-7 \%$ case } & \multicolumn{3}{|c|}{$+7 \%$ case } \\
\hline & Ice & Oc & $\mathrm{I}+\mathrm{O}$ & Ice & Oc & $\mathrm{I}+\mathrm{O}$ \\
\hline Coverage $(\%)$ & 59.0 & 25.3 & 84.3 & 71.0 & 13.3 & 84.3 \\
\hline Vertically integrated air temperature $\left({ }^{\circ} \mathrm{C}\right)$ & -28.8 & -28.9 & -28.8 & -29.3 & -29.5 & -29.3 \\
\hline First-layer air temperature $\left({ }^{\circ} \mathrm{C}\right)$ & -2.8 & -2.9 & -2.8 & -2.9 & -3.3 & -3.0 \\
\hline Surface air temperature $\left({ }^{\circ} \mathrm{C}\right)$ & -1.0 & -1.0 & -1.0 & -1.1 & -1.3 & -1.1 \\
\hline Ocean/ice ground temperature $\left({ }^{\circ} \mathrm{C}\right)$ & -1.0 & -0.6 & -0.9 & -1.0 & -0.5 & -0.9 \\
\hline Second-layer ice temperature $\left({ }^{\circ} \mathrm{C}\right)$ & -1.2 & NA & NA & -1.2 & NA & NA \\
\hline Atmospheric water vapor (mm) & 9 & 9 & 9 & 8.4 & 8.4 & 8.4 \\
\hline Precipitation $\left(\mathrm{mm}\right.$ day $\left.^{-1}\right)$ & 1.0 & 1.0 & 1.0 & 1.0 & 1.0 & 1.0 \\
\hline Low clouds $(\%)$ & 56.7 & 56.7 & 56.7 & 57.8 & 57.8 & 57.8 \\
\hline Lowest layer cloud liquid water (ppmm) & NA & NA & 20 & NA & NA & 19 \\
\hline Middle clouds $(\%)$ & 22.8 & 22.8 & 22.8 & 23.3 & 23.3 & 23.3 \\
\hline High clouds $(\%)$ & 3.0 & 3.0 & 3.0 & 2.7 & 2.7 & 2.7 \\
\hline Total cloud cover $(\%)$ & 68 & 68 & 68 & 68 & 68 & 68 \\
\hline Static stability (potential temperature ${ }^{\circ} \mathrm{km}^{-1}$ ) & 5.8 & 5.8 & 5.8 & 5.8 & 5.9 & 5.82 \\
\hline Shortwave radiation incident at surface $\left(\mathrm{W} \mathrm{m}^{-2}\right)$ & 140 & 135 & 138 & 143 & 137 & 142 \\
\hline Surface ground albedo $(\%)$ & 45 & 10 & 35 & 46 & 10 & 40 \\
\hline Shortwave radiation absorbed at surface $\left(\mathrm{W} \mathrm{m} \mathrm{m}^{-2}\right)$ & 76 & 121 & 90 & 77 & 123 & 84 \\
\hline Longwave radiation incident at surface $\left(\mathrm{W} \mathrm{m}^{-2}\right)$ & 272 & 272 & 272 & 271 & 269 & 271 \\
\hline Longwave radiation outgoing at surface $\left(\mathrm{W} \mathrm{m} \mathrm{m}^{-2}\right)$ & -311 & -311 & -311 & -311 & -312 & -311 \\
\hline Net longwave radiation at surface $\left(\mathrm{W} \mathrm{m}^{-2}\right)$ & -39 & -39 & -39 & -40 & -43 & -40 \\
\hline Net radiation at surface $\left(\mathrm{W} \mathrm{m}^{-2}\right)$ & 38 & 83 & 51 & 37 & 80 & 44 \\
\hline Sensible heat flux $\left(\mathrm{W} \mathrm{m}^{-2}\right)$ & -4 & -5 & -4 & -4 & -8 & -5 \\
\hline Evaporative heat flux $\left(\mathrm{W} \mathrm{m}^{-2}\right)$ & -9 & -10 & -9 & -9 & -12 & -9 \\
\hline Precipitation heat flux (W m $\left.{ }^{-2}\right)$ & -3 & -3 & -3 & -3 & -3 & -3 \\
\hline Net turbulent flux at surface $\left(\mathrm{W} \mathrm{m}^{-2}\right)$ & -16 & -18 & -16 & -16 & -23 & -17 \\
\hline Net heat at surface $\left(\mathrm{W} \mathrm{m}^{-2}\right)$ & 21 & 64 & 34 & 21 & 57 & 27 \\
\hline Upward heat flux from bottom ice layer $\left(\mathrm{W} \mathrm{m}^{-2}\right)$ & 0 & NA & NA & 0 & NA & NA \\
\hline
\end{tabular}

ppmm $=$ parts per million by mass NA $=$ not available.

in the $-7 \%$ case is $\left(-30.9^{\circ} \mathrm{C} \times 73 \%-1.3^{\circ} \mathrm{C} \times 11.3 \%\right) /$ $84.3 \%=-26.9^{\circ} \mathrm{C}$, while the weighted ground temperature in the $+7 \%$ case is $\left(-39.2^{\circ} \mathrm{C} \times 82 \%-1.2^{\circ} \mathrm{C} \times\right.$ $2.3 \%) / 84.3 \%=-38.2^{\circ} \mathrm{C}$, with both the lower ice temperature and the higher ice concentration in the $+7 \%$ case clearly contributing to the large zonal temperature difference.

The ground temperature over the ice in each grid cell is determined by a surface energy balance containing the following terms: shortwave radiation, longwave radiation, sensible heat, evaporative heat, a heat flux carried by precipitation, and a conductive flux from below. The relative importance of the individual terms naturally varies with location and time of year; and, in particular, as there is no shortwave radiation incident at $80^{\circ}-84^{\circ} \mathrm{N}$ during February, the February ground temperature dif-

TABLE 5. Energy sources and sinks $\left(\mathrm{W} \mathrm{m}^{-2}\right)$ for the vertically integrated atmosphere at $80^{\circ}-84^{\circ} \mathrm{N}$, for the Feb and Aug results of the $-7 \%$ and $+7 \%$ cases.

\begin{tabular}{lrrrr}
\hline \hline & $-7 \%$ & $+7 \%$ & $-7 \%$ & $+7 \%$ \\
& Feb & Feb & Aug & Aug \\
\hline Shortwave absorption & 0 & 0 & 66 & 66 \\
Longwave radiation & -127 & -123 & -176 & -174 \\
Sensible heat & 14 & -4 & 2 & 2 \\
Condensation & 12 & 8 & 28 & 28 \\
Dry static energy convergence & 80 & 100 & 50 & 30 \\
Net change & -21 & -19 & -30 & -48 \\
\hline
\end{tabular}

ference between the two cases cannot be associated with solar heating. In contrast, the longwave radiation incident at the surface is a major factor, being much larger with reduced sea ice (Table 3 ), due to the much greater energy radiated downward by the warmer atmospheric column. The water vapor difference (1.2 versus $1.0 \mathrm{~mm}$ ) is inconsequential in this respect, the atmosphere being quite dry regardless of the sea ice amounts, but the greater low cloud cover and the greater cloud liquid water content in the reduced sea ice case contribute significantly. The greater longwave radiation incident at the ice surface in the $-7 \%$ case more than compensates for the increased outgoing longwave energy due to the higher ground temperature, making the net longwave energy loss from the sea ice slightly less in the $-7 \%$ case (Table 3). Weighted over the sea ice/ocean area as a whole, the net longwave loss is greater in the $-7 \%$ case ( $40 \mathrm{vs} 31 \mathrm{~W} \mathrm{~m}^{-2}$ ), due to the greater area of open ocean, but the cloud cover change has mitigated the difference. In fact, of the many polar-unique feedbacks (Kellogg 1975), the ice-cloud feedback seems to dominate the simulated response in these comparisons. The low cloud cover has increased in the reduced sea ice case partly because of increased evaporation and partly because the atmospheric stability decreased in the presence of the warmer lower atmosphere. Combining the nonexistent shortwave flux with the longwave flux, the net radiation at the surface is negative for both the ice 
and the water in both the $-7 \%$ and $+7 \%$ simulations, although the radiative loss is $2 \mathrm{~W} \mathrm{~m}^{-2}$ less over ice and $9 \mathrm{~W} \mathrm{~m}^{-2}$ more weighted over ice and ocean in the $-7 \%$ case (Table 3 ).

As for the turbulent fluxes, over sea ice the sensible heat flux is downward (positive values in Table 3) in both runs, while it is strongly upward over the open ocean areas. Given the greater area of ice-free ocean with the reduced sea ice in the $-7 \%$ case, the total sensible heat flux loss is $23 \mathrm{~W} \mathrm{~m}^{-2}$ greater than in the $+7 \%$ case. Similarly, the total evaporative heat flux loss is $8 \mathrm{~W} \mathrm{~m}^{-2}$ greater in the $-7 \%$ case than in the $+7 \%$ case (Table 3), and the energy loss due to cold precipitation hitting the combined ice and ocean surfaces is 1 $\mathrm{W} \mathrm{m}^{-2}$ greater in the $-7 \%$ case. Hence, overall, the net turbulent flux loss from the ice and ocean surfaces is $32 \mathrm{~W} \mathrm{~m}^{-2}$ more in the $-7 \%$ versus the $+7 \%$ case (Table 3 ). Adding the radiative and turbulent fluxes, the net heating at the surface due to interactions with the atmosphere (abbreviated "net heat at surface" in the tables) is negative in both simulations, but zonally averaged for the ocean and sea ice together, it is $41 \mathrm{~W}$ $\mathrm{m}^{-2}$ more negative for the $-7 \%$ case than the $+7 \%$ case $\left(-75\right.$ versus $\left.-34 \mathrm{~W} \mathrm{~m}^{-2}\right)$, due in large part to the lesser sea ice coverage (Table 3 ). Over the sea ice itself, the net heat at the surface is $4 \mathrm{~W} \mathrm{~m}^{-2}$ less negative for the $-7 \%$ case, a difference that is nearly balanced by a difference in the conductive flux from below of opposite sign ( 11 versus $16 \mathrm{~W} \mathrm{~m}^{-2}$ ). The $-7 \%$ case has a smaller conductive heat flux through the ice because of the smaller vertical temperature gradient within the ice. In fact, the sea ice surface is in approximate equilibrium in each of the runs during this month, with the sum of the net heat at the surface and the upward heat flux from the bottom ice layer being $-2 \mathrm{~W} \mathrm{~m}^{-2}$ in the $-7 \%$ case and $-1 \mathrm{~W} \mathrm{~m}^{-2}$ in the $+7 \%$ case (Table 3 ).

Because the SSTs are prevented from changing, the ocean, in a sense, represents a limitless source of heat for the atmosphere during winter, as the loss of heat from the ocean does not lead to a cooling and consequent formation of an insulating sea ice cover. The path by which this heat source acts to warm the sea ice surface, whose temperature indeed can change, is indirect. By providing a heat source for the atmosphere, the ocean warms the atmosphere, doing so more for the $-7 \%$ case than the $+7 \%$ case because of the greater amount of open water. Because of the stability-related drag coefficient, the warmer atmosphere is inefficient in transporting this heat downward to the ice surface via sensible heat flux, instead radiating the energy downward and reducing the net longwave energy loss from the ice surface (Table 3 ). In addition, the increased evaporative heat flux loss from the combined ice/ocean region provides moisture for the low-level clouds that are acting as longwave energy absorbers and reemitters. Cloud absorption of longwave radiation then produces a downward flux to the surface. Hence, the sea ice surface warms via this indirect pathway: sensible heat flux from the ocean surface, longwave radiation to the atmosphere, and longwave radiation back down to the sea ice surface. The warming continues until the gain of energy has raised the sea ice temperature sufficiently to restore equilibrium via longwave radiation from the sea ice surface.

Energy balance results for the vertically integrated February atmosphere at $80^{\circ}-84^{\circ} \mathrm{N}$ (including the land area) are shown in the first two data columns of Table 5 . With reduced sea ice $(-7 \%$ case) and warmer atmospheric temperatures, more longwave radiation is lost to space, and less energy is gained by atmospheric convergence of dry static energy (the latitudinal temperature gradient has been reduced). These differences are compensated by increased sensible heat gain (from the greater open ocean) and increased condensational heating, with more precipitation. The result is a similar value of net cooling (net change) during the month of February in the two experiments. Note that, in February at $80^{\circ}-84^{\circ} \mathrm{N}$, the nonlocal effects, associated with advection of dry static energy, are working in opposition to the local effects of sensible heating, the former tending to cool the atmosphere in the $-7 \%$ versus the $+7 \%$ case and the latter tending to warm it (Table 5).

Summer results, $80^{\circ}-84^{\circ} \mathrm{N}$. Table 4 presents the $80^{\circ}-$ $84^{\circ} \mathrm{N}$ zonally averaged results for August. The surface air temperatures over the ice and weighted over the ice and ocean are now only slightly higher for the $-7 \%$ case than for the $+7 \%$ case, and the ground temperatures of the ice and weighted between the ice and ocean are now identical to the nearest tenth of a degree for the two cases (Table 4). Again, as in February, these temperatures are determined by energy balances, although now the energy balances include a shortwave radiation term. Starting with that term, the shortwave radiation incident at the combined ice/ocean surface is slightly less in the $-7 \%$ case than in the $+7 \%$ case, due to the greater atmospheric water content and high cloud cover, and the ground albedo is less, due to the reduced sea ice. The net result is $6 \mathrm{~W} \mathrm{~m}^{-2}$ greater shortwave radiation absorbed over the region in the $-7 \%$ case, clearly due to the lesser ice coverage, as neither the ice surface nor the ocean surface had greater shortwave absorption than in the $+7 \%$ case (Table 4 ). Furthermore, the warmer atmosphere in the reduced sea ice case radiates slightly more longwave energy down to the surface, and the net longwave radiation loss from the surface is less in the $-7 \%$ versus $+7 \%$ case, although only by $1 \mathrm{~W} \mathrm{~m}^{-2}$ (Table 4). Combining the shortwave and longwave responses, the net radiation at the ice surface is $1 \mathrm{~W} \mathrm{~m}^{-2}$ greater and weighted over the ice and ocean surfaces is $7 \mathrm{~W} \mathrm{~m}^{-2}$ greater in the reduced sea ice case (Table 4). The positive net values show that the oceans would have warmed radiatively had this been permitted, more so in the reduced sea ice case than in the increased sea ice case.

As for the turbulent fluxes, the gradient between the SST and surface air temperature is lower in the $-7 \%$ 
case, resulting in reduced sensible heat flux away from the ocean surface (Table 4). Similarly, the gradient in specific humidity is also smaller, and so is the evaporative heat flux. These differences, combined with no difference in the precipitation heat flux, result in a smaller net turbulent flux loss from the ocean surface in the $-7 \%$ case, although no difference in net turbulent flux from the ice surface between the two cases and only a $1 \mathrm{~W} \mathrm{~m}^{-2}$ difference when weighted over the ice and ocean surfaces. Combining both the radiative and turbulent fluxes, the net heating at the surface in the $-7 \%$ case is identical to that in the $+7 \%$ case at the ice surface and $7 \mathrm{~W} \mathrm{~m}^{-2}$ greater than that in the $+7 \%$ case at the ocean surface and for the combined ice/ocean surfaces (Table 4). This additional net heat overall in the $-7 \%$ case contributes to warming the ice surface but cannot be used to warm the ocean surface. Had SSTs not been specified, the oceans would have warmed noticeably more in the reduced sea ice case than in the increased sea ice case. In a sense, while the oceans are a limitless heat source during winter in these AMIP-type experiments, they represent a limitless heat sink during summer. Comparing the magnitudes of the radiative and turbulent flux terms, in August the largest factors in the determination of the ground temperature are radiative.

Turning from ground temperatures to atmospheric temperatures, the vertically integrated atmospheric energy balance for August is shown in the last two columns of Table 5. Dry static energy convergence is greater with reduced sea ice, whereas the other four terms are all identical or nearly identical in the two cases, resulting in a smaller net cooling of the $80^{\circ}-84^{\circ} \mathrm{N}$ atmosphere during the month of August in the $-7 \%$ versus $+7 \%$ case (Table 5 ). This difference being due entirely to the difference in the dry static energy convergence, in this sense the gain of energy helping to keep the atmosphere warm, and thus radiate energy down to the surface, is a nonlocal process in this month. The small temperature gradient between the atmosphere and ocean during summer limits the summer surface fluxes and surface air temperature change. In addition, the reduced static stability versus February (Tables 3-4) keeps less of the August atmospheric warming near the surface.

\section{d. Full seasonal cycle}

For a more complete depiction of the seasonal cycle, Fig. 6 shows the full seasonal cycle of simulated monthly average surface air temperatures for each of the 17 simulations, doing so for the Northern and Southern Hemispheres separately and for the global average. The following points show up clearly from these monthly averages.

1) In both hemispheres the expected seasonal contrast is found in all 17 simulations, with Northern Hemisphere temperatures rising from minimum values in
January and February to maximum values in July and August and Southern Hemisphere temperatures rising from minimum values in July and August to maximum values in January and February (Fig. 6).

2) For each month, the ordering of the curves is largely as expected, with temperatures rising as the ice concentration amount is reduced step by step from the $+50 \%$ case to the $-50 \%$ case. There are exceptions, however, as the curves do cross.

3) The Northern Hemisphere exhibits a much stronger seasonal contrast than the Southern Hemisphere, with a summer/winter temperature contrast of approximately $13^{\circ} \mathrm{C}$ for the Northern Hemisphere compared to approximately $5.5^{\circ} \mathrm{C}$ for the Southern Hemisphere. The substantially greater annual range in temperatures in the Northern versus Southern Hemisphere is expected from the substantially greater land area in the Northern Hemisphere and is confirmed by observations (e.g., Strahler 1973).

4) The timing of the global seasonal cycle follows closely that of the Northern Hemisphere cycle. This also is confirmed by observations, for example, with Susskind (1993) finding a strong seasonal cycle in global temperatures from a minimum in January to a maximum in July, from High Resolution Infrared Radiation Sounder and Microwave Sounding Unit satellite data for 1979-80.

5) In both hemispheres the surface air temperature response to ice concentration changes is far greater in winter than in summer. In the Northern Hemisphere, the August average temperatures vary by only $0.23^{\circ} \mathrm{C}$, from $20.58^{\circ}$ to $20.81^{\circ} \mathrm{C}$, among the 17 simulations, while the January average temperatures vary by $2.05^{\circ} \mathrm{C}$, from $7.16^{\circ}$ to $9.21^{\circ} \mathrm{C}$, among the 17 simulations. In the Southern Hemisphere, the January summertime variation is $0.22^{\circ} \mathrm{C}$, from $15.32^{\circ}$ to $15.54^{\circ} \mathrm{C}$, whereas the August midwinter variation is $1.47^{\circ} \mathrm{C}$, from $9.10^{\circ}$ to $10.57^{\circ} \mathrm{C}$. For global averages, the range in the temperature response among the 17 simulations is naturally much more uniform throughout the year, as the responses in the opposing seasons for the two hemispheres are averaged together (Fig. 6).

6) The wintertime surface air temperatures, especially in the Northern Hemisphere, have a stronger response to sea ice decreases than to sea ice increases, as discussed earlier in connection with Fig. 4.

The second to last point in particular is of relevance to the issue of the impact of satellite retrieval accuracies. As mentioned in the introduction, satellite-retrieved ice concentrations are thought to be less accurate in summer than in winter because of the summertime complications deriving from snow and ice melt. Summer, however, is also the time with the smallest simulated response to the imposed ice concentration changes (Fig. 6 and point 5 above), thus yielding the favorable coincidence that the satellite is at its worst when any inaccuracies it might 

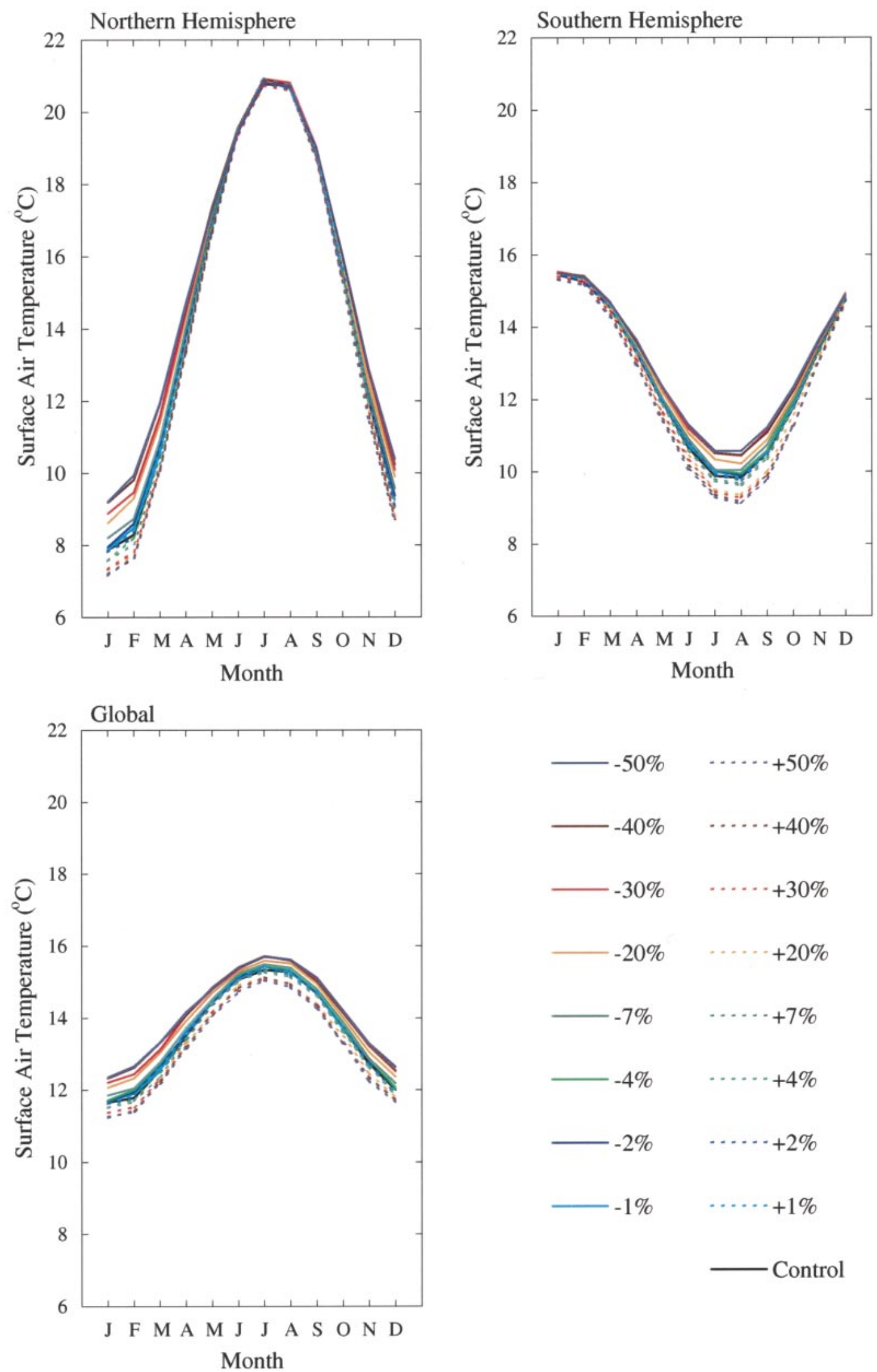

FIG. 6. Full seasonal cycle of the monthly average surface air temperatures in each of the 17 simulations, for the Northern Hemisphere, Southern Hemisphere, and global values. 


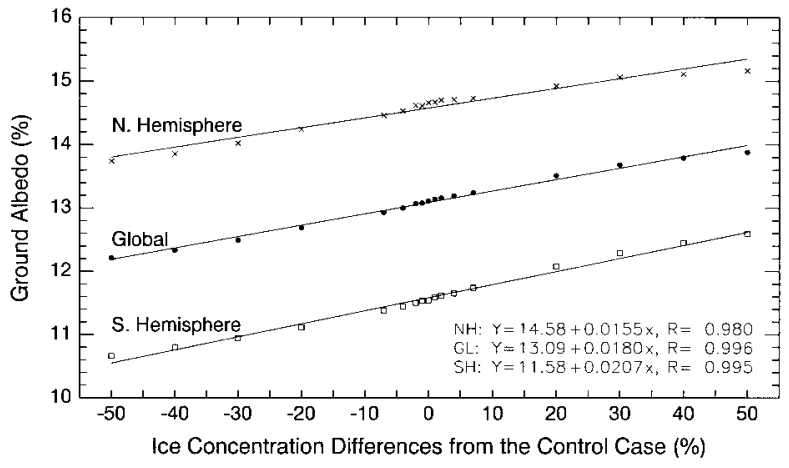

FIG. 7. Global and hemispheric annually averaged ground albedo (\%) for each of 17 simulations, with lines of linear least squares fit through the global, Northern Hemisphere, and Southern Hemisphere values. All values are averaged over the five simulation years 3-7. Least squares fit equations are shown for each of the three lines, along with the corresponding linear correlation coefficients $(R$ values).

generate have the least impact on the simulated results. With this in mind, use of annual averages earlier likely overestimates the impact that the satellite inaccuracies might have. For instance, if the 7\% overall inaccuracy estimated for current sensors reflects a $10 \%$ inaccuracy in summer and a $6 \%$ inaccuracy in the other three seasons, then the global response in each month approaches the $6 \%$ response rather than the $7 \%$ response, because in April, May, June, October, November, and December, both hemispheres would be subject to the $6 \%$ inaccuracy, while in January, February, and March the Northern Hemisphere, with its strong wintertime response to the concentration changes, would be subject to the $6 \%$ inaccuracy and the Southern Hemisphere, with its weak summertime response to the concentration changes, would be subject to the $10 \%$ inaccuracy, and reversely in July, August, and September. From Fig. 6, it is clear that the contribution of the Northern (Southern) Hemisphere to the global temperature-range results in July, August, and September (January, February, and March) is small and would not differ greatly for a $6 \%$ versus $10 \%$ ice concentration change. Hence the global impact on simulated temperatures of satellite inaccuracies in

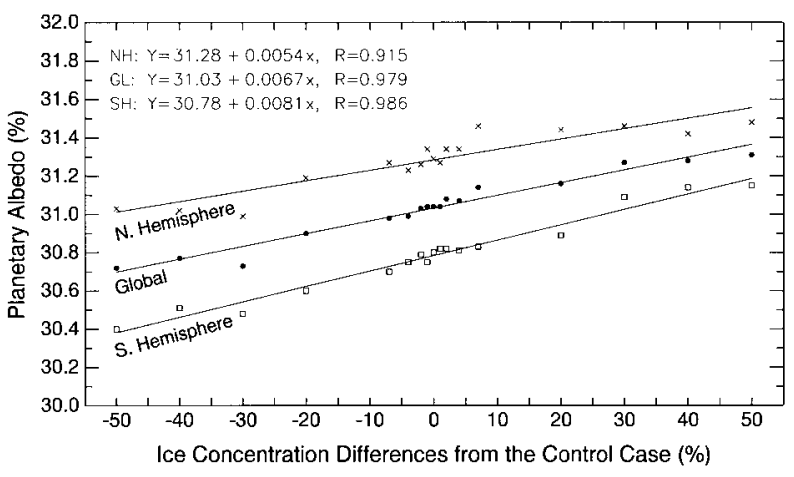

FIG. 8. Same as Fig. 7 except for planetary albedo (\%).

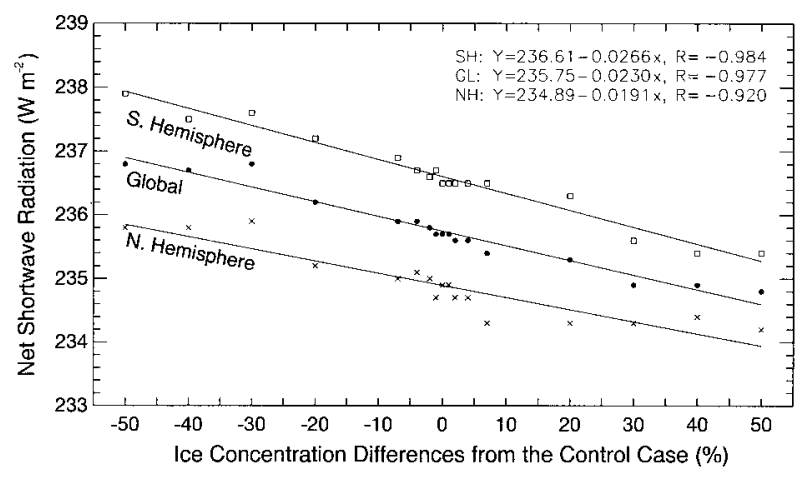

FIG. 9. Same as Fig. 7 except for net shortwave radiation at the top of the atmosphere $\left(\mathrm{W} \mathrm{m}^{-2}\right)$.

ice concentration of $10 \%$ in summer and $6 \%$ in the other three seasons would be closer to the impact of a $6 \%$ uniform change throughout the year than to the impact of a 7\% change. Similarly, the global impact on simulated temperatures of improved satellite inaccuracies in ice concentration of $7 \%$ in summer and $3 \%$ in the other three seasons (averaging to $4 \%$ annually) would be closer to a $3 \%$ impact overall than to a $4 \%$ impact overall, again because of the minimal simulated response in summer.

\section{e. Radiative characteristics}

To examine additional sea-ice-induced changes in the results, we present simulated global and hemispheric radiative characteristics for these experiments (Figs. 710). As expected, as the highly reflective sea ice cover increases, both ground albedo (Fig. 7) and planetary albedo (Fig. 8) increase, with the greater impact being on the ground albedo. The global ground albedo increases from $12.2 \%$ in the $-50 \%$ ice case to $13.9 \%$ in the $+50 \%$ ice case, for an additive increase of $1.7 \%$ and a percentage increase of $14 \%$ (Fig. 7). Due to the influence of clouds, which are like sea ice in being highly reflective but unlike sea ice in spreading over a much greater area of the earth, the planetary albedo is affected far less than the ground albedo. In the global case, plan-

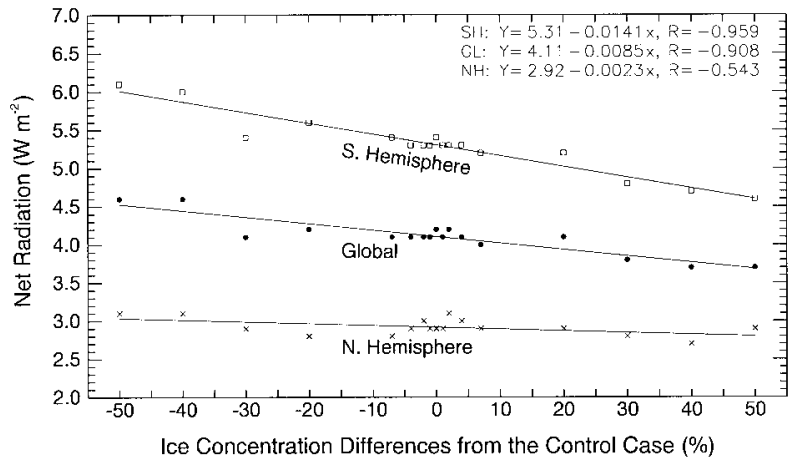

Fig. 10. Same as Fig. 7 except for net radiation at the top of the atmosphere $\left(\mathrm{W} \mathrm{m}^{-2}\right)$. 
etary albedo increases from $30.72 \%$ in the $-50 \%$ ice case to $31.31 \%$ in the $+50 \%$ ice case, for an additive increase of $0.59 \%$ and a percentage increase of $1.9 \%$ (Fig. 8). The planetary albedo change results in a decrease in net shortwave radiation at the top of the atmosphere from $236.8 \mathrm{~W} \mathrm{~m}^{-2}$ in the $-50 \%$ ice case to $234.8 \mathrm{~W} \mathrm{~m}^{-2}$ in the $+50 \%$ ice case (Fig. 9), for a $0.8 \%$ decrease, also derivable directly from the two planetary albedos.

The global results, and in most cases the hemispheric results, for ground albedo (Fig. 7), planetary albedo (Fig. 8), net shortwave radiation (Fig. 9), and surface air temperature (Fig. 3) are all approximately linear with sea ice change, with linear correlation coefficients exceeding 0.95 . The linearity is considerably weaker for net longwave radiation (with linear correlation coefficients of 0.87 for each hemisphere separately and 0.91 for the global results), which responds both to temperature changes directly and to alterations in the atmospheric greenhouse capacity (e.g., water vapor changes) developed in response to the temperature changes brought on by the sea ice changes. The combined impact of the altered longwave and shortwave radiation is presented in Fig. 10, as the net radiation at the top of the atmosphere. Because of the specified SSTs, energy absorbed in the ocean is not allowed to warm the water, hence preventing full conservation of energy and resulting in nonzero net radiation at the top of the atmosphere. In the coldest climate, with $50 \%$ increases in sea ice concentrations, the net radiation has decreased relative to the control run by about $0.5 \mathrm{~W} \mathrm{~m}^{-2}$, whereas in the warmest climate, with $50 \%$ decreases in sea ice concentration, the net radiation has increased relative to the control run by about $0.4 \mathrm{~W} \mathrm{~m}^{-2}$ (Fig. 10).

\section{Summary and discussion}

Results of sensitivity studies with the GISS GCM and interannually invariant ocean boundary conditions show that differences of $\pm 7 \%$ in sea ice concentrations, the current estimated accuracy of satellite ice concentration retrievals, have an effect on the simulated monthly average surface air temperatures that can exceed $6^{\circ} \mathrm{C}$ locally within the polar regions but is much smaller in nonpolar regions (Figs. 1-2). The effect is smaller also when examined on the basis of yearly average global or hemispheric values (Fig. 3; Table 2). Narrowing the range of sea ice concentration adjustments from $\pm 7 \%$ to $\pm 4 \%$ reduces by a third the resulting simulated range in annually averaged global temperatures, from $0.27^{\circ}$ to $0.18^{\circ} \mathrm{C}$ (Table 2 ), with a greater impact in the Northern Hemisphere than in the Southern Hemisphere (Table 2). Furthermore, the $\pm 4 \%$ cases show almost no areas with temperatures deviating from the control case by as much as $6^{\circ} \mathrm{C}$ (e.g., Figs. 4-5). Because ice concentration retrieval accuracies are worst in summer, when the impact of ice concentration changes on the simulated temperatures is least (Fig. 6), the overall impact of the ice retrieval uncertainties should be even less than what the use of annually averaged values indicates. Similarly, the fact that errors in the satellite retrievals are at least in part random rather than systematic also tends to reduce their impact versus the impact of the systematic changes imposed on the model simulations.

Over a wider range of specified ice concentration changes, least squares fits through the temperature results of 17 simulations with ice concentration changes ranging from decreases of $50 \%$ versus the control run to increases of $50 \%$ yield a yearly average global impact of $0.0107^{\circ} \mathrm{C}$ warming for every $1 \%$ ice concentration decrease and $1.07^{\circ} \mathrm{C}$ warming for the full $+50 \%$ to $-50 \%$ range in ice concentration adjustments (Fig. 3). Regionally and on a monthly average basis, the differences can be far greater, especially in the polar regions, where wintertime contrasts between the $+50 \%$ and $-50 \%$ cases can exceed $30^{\circ} \mathrm{C}$ (Figs. $4-5$ ).

In an earlier study, Simmonds and Budd (1990) examined the effect on a GCM simulation of altering the ice concentrations from a full $100 \%$ wherever ice exists to $50 \%$ for all south polar ice and $95 \%$ for all north polar ice. Their interest was specifically in examining the impact of changes in wintertime Antarctic ice concentrations, hence, the much more substantial assigned change in south polar ice concentrations than in north polar concentrations. Also, they ran their model in a perpetual-July mode, again in line with their emphasis on wintertime Antarctic conditions. In the vicinity of the Antarctic ice, they found warming of up to $6^{\circ} \mathrm{C}$, reductions in atmospheric pressure, and increases in sensible heat flux that in some areas exceeded $200 \mathrm{~W} \mathrm{~m}^{-2}$. The current study shows that regional impacts can be pronounced even when much lesser changes in assigned ice concentrations are made and when the full seasonal cycle is simulated.

As noted by Hansen et al. (1997), the 1979-93 trends implied from the sea ice boundary conditions used in selected AMIP studies are much larger than interannual variations. (The 1979-93 AMIP sea ice values were formed from three datasets, with discontinuities at the end of 1981 and the end of 1987.) For doubled $\mathrm{CO}_{2}$ simulations, the modeled sea ice responses are even larger, with some of the simulated ice cover changes exceeding the $\pm 50 \%$ changes used here for our extreme cases (Hansen et al. 1984). Not surprisingly, the effects on modeled polar surface air temperature trends can be quite high. Our results suggest that some local simulated surface air temperature changes of $10^{\circ} \mathrm{C}$ or more would be likely from such variations. However, impacts at this level are simulated only in the polar regions; few statistically significant differences are found at lower latitudes.

Regarding variables other than surface air temperature, linear least squares fits through results from the 17 simulations yield yearly average global impacts that include increases (additive) in ground albedo of $0.0180 \%$ and in planetary albedo of $0.0067 \%$ for every $1 \%$ ice 
concentration increase (Figs. 7-8), plus net shortwave radiation decreases of $0.0230 \mathrm{~W} \mathrm{~m}^{-2}$ for every $1 \%$ ice concentration increase (Fig. 9) and net radiation decreases of $0.0085 \mathrm{~W} \mathrm{~m}^{-2}$ for every $1 \%$ ice concentration increase (Fig. 10).

The results throughout this paper describe simulated changes induced by changes in sea ice while the annual cycle of SSTs is kept invariant. Not allowing SSTs to change from one simulation to another prevents feedback and propagation effects through SST and hence restricts the water vapor and cloud responses and the albedo-temperature feedback, thereby dulling the responses outside the polar regions. Inclusion of a more complete ocean model would likely alter the responses in both polar and nonpolar regions.

Acknowledgments. We thank John Eylander of Raytheon Information Technology and Scientific Services for assistance in the generation of the plots and Gary Russell and Jean Lerner for help in model diagnostics. This work was supported by the NASA Polar Program Office.

\section{REFERENCES}

Battisti, D. S., C. M. Bitz, and R. E. Moritz, 1997: Do general circulation models underestimate the natural variability in the Arctic climate? J. Climate, 10, 1909-1920.

Bjørgo, E., O. M. Johannessen, and M. W. Miles, 1997: Analysis of merged SMMR-SSMI time series of Arctic and Antarctic sea ice parameters 1978-1995. Geophys. Res. Lett., 24, 413-416.

Bromwich, D. H., R. Y. Tzeng, and T. R. Parish, 1994: Simulation of the modern Arctic climate by the NCAR-CCM1. J. Climate, 7, 1050-1069.

Cattle, H., and J. Crossley, 1995: Modeling Arctic climate change. Philos. Trans. Roy. Soc. London, 352A, 201-213.

Del Genio, A. D., M. S. Yao, W. Kovari, and K. K. W. Lo, 1996: A prognostic cloud water parameterization for global climate models. J. Climate, 9, 270-304.

Emery, W. J., C. Fowler, and J. Maslanik, 1994: Arctic sea ice concentrations from special sensor microwave imager and advanced very high resolution radiometer satellite data. J. Geophys. Res. 99, 18 329-18 342

Folland, C. K., D. M. H. Sexton, D. J. Karoly, C. E. Johnson, D. P. Rowell, and D. E. Parker, 1998: Influences of anthropogenic and oceanic forcing on recent climate change. Geophys. Res. Lett., 25, 353-356.

Gates, W. L., 1992: AMIP: The Atmospheric Model Intercomparison Project. Bull. Amer. Meteor. Soc., 73, 1962-1970.

Gloersen, P., W. J. Campbell, D. J. Cavalieri, J. C. Comiso, C. L. Parkinson, and H. J. Zwally, 1992: Arctic and Antarctic Sea Ice, 1978-1987: Satellite Passive-Microwave Observations and
Analysis. National Aeronautics and Space Administration, 290 pp.

Hansen, J., G. Russell, D. Rind, P. Stone, A. Lacis, S. Lebedeff, R. Ruedy, and L. Travis, 1983: Efficient three-dimensional global models for climate studies: Models I and II. Mon. Wea. Rev., 111, 609-662.

, A. Lacis, D. Rind, G. Russell, P. Stone, I. Fung, R. Ruedy, and J. Lerner, 1984: Climate sensitivity: Analysis of feedback mechanisms. Climate Processes and Climate Sensitivity, J. E. Hansen and T. Takahashi, Eds., Amer. Geophys. Union, 130-163.

and Coauthors, 1997: Forcings and chaos in interannual to decadal climate change. J. Geophys. Res., 102, 25 679-25 720.

Hartke, G., and D. Rind, 1997: Improved surface and boundary layer models for the GISS GCM. J. Geophys. Res., 102, $16407-$ 16422 .

Kellogg, W. W., 1975: Climatic feedback mechanisms involving the polar regions. Climate of the Arctic, G. Weller and S. A. Bowling, Eds., Geophysical Institute, University of Alaska Fairbanks, 111-116.

Lindzen, R., 1990: Some coolness concerning global warming. Bull. Amer. Meteor. Soc., 71, 288-299.

McGinnis, D. L., and R. G. Crane, 1994: A multivariate analysis of Arctic climate in GCMs. J. Climate, 7, 1240-1250.

Parkinson, C. L., J. C. Comiso, H. J. Zwally, D. J. Cavalieri, P. Gloersen, and W. J. Campbell, 1987: Arctic Sea Ice, 1973-1976: Satellite Passive-Microwave Observations. National Aeronautics and Space Administration, $296 \mathrm{pp}$.

— - D. J. Cavalieri, P. Gloersen, H. J. Zwally, and J. C. Comiso, 1999: Arctic sea ice extents, areas, and trends, 1978-1996. J. Geophys. Res., 104, 20 837-20 856.

Rind, D., 1998: Latitudinal temperature gradients and climate change. J. Geophys. Res., 103, 5943-5971.

_ and J. Lerner, 1996: The use of on-line tracers as a diagnostic tool in GCM model development. J. Geophys. Res., 101, 12667 12683

_ R. Healy, C. Parkinson, and D. Martinson, 1995: The role of sea ice in $2 \times \mathrm{CO}_{2}$ climate model sensitivity. Part I: The total influence of sea ice thickness and extent. J. Climate, 8, 449463.

,- , and 1997: The role of sea ice in $2 \times \mathrm{CO}_{2}$ climate model sensitivity: Part II: Hemispheric dependencies. Geophys. Res. Lett., 24, 1491-1494.

Robinson, M., and R. Bauer, 1981: Oceanographic Monthly Summary, 1, No. 2, NOAA National Weather Service, 2-3.

Simmonds, I., and W. F. Budd, 1990: A simple parameterization of ice leads in a general circulation model, and the sensitivity of climate to change in Antarctic ice concentration. Ann. Glaciol., 14, 266-269.

Steffen, K., and A. Schweiger, 1991: NASA team algorithm for sea ice concentration retrieval from Defense Meteorological Satellite Program Special Sensor Microwave Imager: Comparison with Landsat satellite imagery. J. Geophys. Res., 96, 21 971-21987.

Strahler, A. N., 1973: Introduction to Physical Geography. 3d ed. John Wiley \& Sons, 468 pp.

Susskind, J., 1993: Water vapor and temperature. Atlas of Satellite Observations Related to Global Change, R. J. Gurney, J. L. Foster, and C. L. Parkinson, Eds., Cambridge University Press, $89-128$.

Walsh, J. E., and R. G. Crane, 1992: A comparison of GCM simulations of Arctic climate. Geophys. Res. Lett., 19, 29-32. 